\title{
Does the US EXIM Bank Really Promote US Exports?*
}

\author{
Natasha Agarwal ${ }^{a}$ and Zheng Wang ${ }^{b, c}$ \\ ${ }^{a}$ World Education Foundation, Norway \\ ${ }^{b}$ Leicester Business School, De Montfort University, Leicester, LE1 9BH, \\ United Kingdom \\ ${ }^{c}$ GEP, University of Nottingham, Nottingham, NG7 2RD, United Kingdom
}

24 May, 2017

\begin{abstract}
This paper investigates the impact of US Export-Import Bank (EXIM) on US exports particularly in the wake of international competition from foreign national export credit agencies (ECAs). We employ a gravity framework on a country-industry-year-level panel dataset that matches EXIM authorizations with US bilateral exports. Our results depict the general ineffectiveness of the Bank in promoting exports within and across industries. Some heterogeneities behind the general finding are also uncovered: industries other than aerospace parts and products are more likely to benefit from EXIM authorizations, and EXIM authorizations to larger businesses seem to be more effective in encouraging exports. Furthermore, we find no evidence that explains the role of EXIM in encouraging US exports by offsetting foreign ECA competition. These results are neither affected by competing countries' membership to the OECD Arrangement nor by the size of American firms that received EXIM support. Our results cast doubt on the ubiquitously positive claims made by the Bank and its supporters, yet also provide policy lessons for countries that are either in the inception stages of establishing their own ECAs or are now placing greater importance on ECA financing in encouraging exports.
\end{abstract}

Key Words: Trade credits; EXIM; export competition; value chain; US

JEL Classifications: F13, F14, F55

${ }^{*}$ We thank seminar participants at Fudan University, Shanghai University of Finance and Economics, and the University of Dundee for their helpful comments, and Magnus Lodefalk and Abishek Choutagunta for their help with some of the data. We also thank Louis Dupuy for his invaluable suggestions. All remaining errors are our own. Responsibility of the views, opinions, suggestions and analysis in this article lies solely with the authors and does not reflect the institutions they belong to. Agarwal: World Education Foundation, Norway; Email: agarwana3@gmail.com. Wang: Leicester Business School, De Montfort University, Leicester, LE1 9BH, United Kingdom; Email: zheng. wang@dmu . ac . uk. 


\title{
Does the US EXIM Bank Really Promote US Exports?
}

\begin{abstract}
This paper investigates the impact of US Export-Import Bank (EXIM) on US exports particularly in the wake of international competition from foreign national export credit agencies (ECAs). We employ a gravity framework on a country-industry-year-level panel dataset that matches EXIM authorizations with US bilateral exports. Our results depict the general ineffectiveness of the Bank in promoting exports within and across industries. Some heterogeneities behind the general finding are also uncovered: industries other than aerospace parts and products are more likely to benefit from EXIM authorizations, and EXIM authorizations to larger businesses seem to be more effective in encouraging exports. Furthermore, we find no evidence that explains the role of EXIM in encouraging US exports by offsetting foreign ECA competition. These results are neither affected by competing countries' membership to the OECD Arrangement nor by the size of American firms that received EXIM support. Our results cast doubt on the ubiquitously positive claims made by the Bank and its supporters, yet also provide policy lessons for countries that are either in the inception stages of establishing their own ECAs or are now placing greater importance on ECA financing in encouraging exports.
\end{abstract}

Key Words: Trade credits; EXIM; export competition; value chain; US

JEL Classifications: F13, F14, F55 


\section{Introduction}

The positive role of trade financing in facilitating international trade is ubiquitously agreed and confirmed by researchers (e.g. Chor and Manova, 2012; Manova, 2013). Nevertheless, the impact of trade financing provided by national export credit agencies (ECAs) is much less in the clear. While one camp advocates ECA financing and endorses its positive effect on a country's exports and jobs, the other camp doubts the efficiency of this non-market intervention and raises concern about the unintended distortions brought about by such government interventions. ${ }^{1}$ In the US, this debate reached its climax when its Export-Import Bank (EXIM), the official export credit agency (ECA) of the country, closed to new business after June 30, 2015. ${ }^{2}$ Despite the sharp controversy around the functions of the EXIM Bank, surprisingly no systematic evidence exists in the academic literature regarding the effectiveness of the US EXIM Bank in promoting trade.

In this paper, we attempt to steer this debate into clarity by investigating whether and how - if any - support (in the form of authorizations) provided by the US EXIM Bank affects US exports. We try to uncover the heterogeneity under this potential export-promoting effect of EXIM authorization across various dimensions including industries, regions, and size of American companies that received EXIM support. ${ }^{3}$ We then move on to examining whether the potential export-promoting effect of EXIM authorization is affected by competition from other countries' ECA-financed exporting activities particularly in the wake of international institutional arrangements such as the OECD Arrangement on Officially Supported Export Credits (the Arrangement hereafter).

Using panel data on US export flows disaggregated by receiving country, industry, and year, our first set of results provide no detectable evidence on the export-promoting effects of EXIM authorization. However, further inspection reveals that this insignificant effect masks heterogeneities: EXIM authorizations to all sectors, except for aerospace products and parts (NAICS 3364), have a significantly positive, albeit small effect on US exports, and that this effect is only observable for American companies that are not classified as small by the Bank. ${ }^{4}$ Furthermore, we find that the positive average export-promoting effect of EXIM authorization is not affected by competition from exporting activities financed by foreign governments' ECAs, and that this effect is neither affected by foreign governments' accession to the Arrangement nor by the size of American companies that received EXIM assistance. In addition, the general ineffectiveness of EXIM authorization is robust when taking into account the heterogeneity with an industry's position in the value chain, and when accounting for the possibility of influences that may spill over across sectors.

The above results have important policy implications for policymakers in the US as well as in other countries. Our research highlights the importance of going beyond evaluating a general export-

\footnotetext{
${ }^{1}$ See James (2011) for a review of the viewpoints of both camps.

${ }^{2}$ On December 4, 2015, the Bank was reauthorized by the Congress for business as usual.

${ }^{3}$ We look at these dimensions because of its explicit focus in the US EXIM Bank Charter.

${ }^{4}$ The US EXIM Bank adopts the qualifying criteria for "small business" from the U.S. Small Business Administration (SBA) definition. SBA has established a "Table for Small Business Size Standards" for industries in the North American Industry Classification System, where the size standards are based on either annual sales or average employment. The latest table updated on February 26, 2016 can be accessed from the SBA website at https://www.sba.gov/sites/default/ files/files/Size_Standards_Table.pdf.
} 
promoting effect of ECA financing, and exploring the heterogeneity behind this general effect that is related to country and industry characteristics. It calls attention to the significance of ECAs in offsetting competition from other countries' ECA-financed exporting activities. Consequently, it revives the political debate on whether resorting to domestic institutions is the answer to improving trade competitiveness without leading to protectionism and market distortions (domestically and internationally. It also rekindles the debate on countries' binding constraints under various international institutional arrangements, and the countering effect on countries' international commitments as a result of their accession to these arrangements.

Our analysis extends the existing studies that establish a positive and significant impact of ECA financing on ECA country exports. In a pioneering study, Egger and Url (2006) analyze Austrian export flows disaggregated by receiving country and 2-digit industry, and show that export credit guarantees extended by Austria's ECA, Oesterreichische Kontrollbank (OeKB), indeed foster economic activity, resulting in a multiplier effect of 2.8. Furthermore, OeKB financing not only results in the broadening of trade partners towards high-risk regions but also leaves the goods structure of foreign trade almost unchanged. Moser et al. (2008) analyze German export flows, disaggregated by receiving country and year, and show that export credit guarantees extended by Germany's official ECA, Euler Hermes (Hermes), do lead to higher German exports with a multiplier effect of about 1.7. The effectiveness of ECA financing crucially hinges on both the sample of countries and the time period considered. Both studies above show a more than proportional effect of export credit guarantees on export volumes with short-run effects of ECA financing on export volumes being smaller than long-run effects. This is argued to be largely because of the lag between the day when a guarantee is authorized and the actual shipment of the good.

In a similar vein, Felbermayr and Yalcin (2013) study German export flows disaggregated also by receiving country and 2-digit industry, and document that a $1 \%$ increase in export credit guarantees extended by Hermes, boosts exports on average by about $0.012 \%$. Moreover, they show that the effectiveness of Hermes in increasing exports varies across sectors, regions and income groups. In particular, Hermes effect is large in a small number of sectors which are aviation, shipbuilding and transportation sector. Characterized by high time-to-build lags and large external financial dependence, these sectors indicate that Hermes' guarantees alleviate sectoral financial frictions. Lastly, they show that Hermes does not play a strong role in reducing the impact of financial frictions in importing countries on German exports. Likewise, the positive Hermes effect becomes smaller for less vulnerable sectors in terms of credit constraints. Additionally, they show that Hermes have helped contain export collapse during the recent financial crisis of 2008, particularly in sectors with higher credit constraints. At a more disaggregated level, Badinger and Url (2013) analyze a cross-section of 178 firms for the year 2008, and show that export credit guarantees extended by OeKB increase firm-exports from some $80 \%$ to $100 \%$. More so, the effect of export credit guarantees is larger for exports to countries with higher credit risk. The generally positive pro-trade impact of trade credits is confirmed in some other studies with data collected either from Berne Union or individual export credit insurer (van der Veer, 2015; Korinek et al., 2010; Auboin and Engemann, 2014).

Our study is also broadly related to the literature which shows that negative shocks to bank- 
intermediated trade finance, particularly at times of financial distress at the banks, reduce the volume of exports for firms that continue exporting to a given product-destination market (i.e. intensive margin), and have no impact on the probability that a firm exists or enters new product or destination markets (i.e. extensive margin) (Amiti and Weinstein, 2011; Paravisini et al., 2014; Prete and Federico, 2014). They argue that lack in bank-intermediated trade finance reduces exports through raising the variable cost of production rather than the sunk cost of entry investments.

Last, our research is linked to an increasing body of literature on the impact of trade finance on a country' level and pattern of international trade, both at the macro- and micro- level (e.g. Chor and Manova, 2012; Manova, 2013; Manova et al., 2015). This line of research argues that financial comparative advantage alleviates the substantial sunk, fixed, and variable costs of trade such that financially developed economies export more, especially in financially vulnerable sectors, through entering more markets, shipping more products to each destination, and selling more of each product.

While our empirical approach is closed related to Egger and Url (2006), Moser et al. (2008), and Felbermayr and Yalcin (2013), we make several distinctive extensions and contributions to this growing body of literature. First, to the best of our knowledge about the academic literature, we provide the first rigorous evaluation of the effectiveness of US EXIM Bank, a dominant player in the world EXIM financing. Second, this is the first paper that provides evidence on whether EXIM authorization enables domestic exporters to overcome the competition emanating from foreign government ECA financing, particularly in cases where foreign government ECAs are acceded to the OECD Arrangement. Finally, we investigate whether and how EXIM financing enables exporters to move up the industrial chain and evolve itself in the global value chain, offering the first evidence of its kind in the context of global production networks.

The rest of the paper is structured as follows. Section 2 sets out the conceptual framework elaborating the possible channels and directions in which ECA financing would affect aggregate exports. Section 3 proposes an empirical gravity model for the estimation of the effect of EXIM support. Section 4 provides an institutional background on the US EXIM Bank. Section 5 describes the data and offers descriptive evidence. Section 6 presents our results and analysis of the possible influencing channels. Section 7 concludes this paper with a discussion on the limitations and possibilities of future research.

\section{Conceptual Framework}

To export is not cost free. It requires substantial upfront costs in the form of sunk, fixed, and variable costs. While export-related sunk and fixed costs could include learning about the profitability of potential export markets, making market-specific investments in capacity/product customization/regulatory compliance, and setting up and maintaining foreign distribution networks, variable costs could include shipping, duties and freight insurance, and any variable production costs (Manova, 2013). These costs have to be incurred before the export revenues are realized where the 
realization can be deferred because of potential delays in cross-border shipping and delivery. ${ }^{5}$

Owing to the risks ${ }^{6}$ associated with the realization of export revenues and yet the financial need to provide for export-related costs tied to and in support of international trade transactions, firms prefer financing through an active trade finance market to utilizing their retained earnings or international cash flows from operations. This preference is evident in the fact that $80 \%$ to $90 \%$ of trade transactions involve some credit, insurance or guarantee, from various players including multilateral financial institutions, regional development banks, ECAs, and commercial institutions (Auboin, 2009b). ${ }^{7}$ While private banks account for some $80 \%$ of the trade finance market through lending (Auboin, 2009b), ECAs are now becoming ever more popular in this market, largely due to the changing role played by ECAs in trade finance: from being lenders/insurers of last resort ${ }^{8}$, to performing secondary market operations in the form of securitization or refinancing guarantees ${ }^{9}$, and to being a public interventionist especially in times of crisis ${ }^{10}$, among others. In a survey conducted by the International Chamber of Commerce, only $6.5 \%$ of the bank respondents agree that ECAs do not help in narrowing trade finance gaps with the remaining $93.5 \%$ agreeing at various levels: $18.5 \%$ agreeing that they help 'very little', $46.7 \%$ agreeing that they help 'somewhat', and $28.3 \%$ agreeing that they help 'to a great extent' (ICC, 2016). ECAs silently assumes risk in the trade finance markets and thereby provide necessary protection in various forms of financial support.

Despite the importance of ECAs in the trade finance market, its implications on country-level exports continues to remain a conundrum. ${ }^{11}$ Does ECA-financing have a positive, negative, or no impact on country exports? If yes, then what are the potential channels through which these effects are mediated?

Existing research including Egger and Url (2006), Moser et al. (2008), and Felbermayr and Yalcin (2013) provide evidence on the positive impact of Austrian and German ECAs have had on

\footnotetext{
${ }^{5}$ Potential delays in cross-border shipping and delivery could be for a number of reasons including port handling, customs clearances, border compliance, and documentary compliance, among others. Manova (2013) reports that typically, cross-border shipping and delivery take 60 days longer to complete than domestic orders.

${ }^{6}$ Risks here could be commercial where one of the parties involved is unable to fulfill its part of the contract. For instance, on the one hand, an exporter may not be able to secure payments for his merchandise in case of bankruptcy or insolvency of the importer or rejection by the importer. On the other hand, the importer bears the risk of alteration or delayed delivery of goods. Besides commercial risk, traders further have to deal with exchange rate fluctuation risk, country risk, transportation risk, and political risk (Auboin and Meier-Ewert, 2003).

${ }^{7}$ See Auboin and Meier-Ewert (2003) for a list of traditional actors and instruments of a trade finance market.

${ }^{8}$ The US EXIM Bank is one such example where the Bank acts as a lender/insurer of last resort for credit-worthy foreign importers of US goods and services.

${ }^{9}$ For instance, the German ECA (Euler-Hermes) provides for a securitization guarantee scheme under the name "Verbriefungsgarantie, details of which can be found at http://www.agaportal.de/en/aga/produkte/ verbriefungsgarantie.html. For more details on securitization and refinancing guarantees scheme see ISMED (2011).

${ }^{10}$ The financial crisis of 2008 witnessed the bulk of the support provided by ECAs essentially with programs for shortterm lending of working capital and credit guarantees aimed at SMEs. While for certain countries the commitment is very large (German and Japan), for other countries very large lines of credit have been granted to secure supplies with key trading partners (Auboin, 2009a). For instance, the US and China agreed that their respective ECAs would make an additional US\$20 billion available for bilateral trade, and the US and South Korea made a similar commitment for US $\$ 3$ billion (https://www.wto.org/english/thewto_e/coher_e/challenges_e.htm). Efforts of government-back institutions heightened due to estimated market gap to be around US $\$ 25$ billion which private sector was unable to provide for.

${ }^{11}$ For simplicity, in our discussion, we assume that all firms in the economic system are eligible for ECA financing, and that firm characteristics such as firm size, firm productivity, amongst others, which could have an impact on the demand for ECA financin, are assumed away.
} 
these countries' exports respectively. They postulate that ECA financing reduces profit uncertainty on the exporter's side stemming from the default risk on the importer's side. Reduction in uncertainty and risks, therefore, encourages exporters to engage in greater cross-border trading activities thereby increasing country exports (Moser et al., 2008).

Risk mitigation being one channel, ECAs also have a positive impact on home-country exports through the liquidity channel. ECAs provide its home-country exporters with liquidity that enables them to overcome their continuous need of export-related costs, and offer foreign importers fluidity to pay for home country products or services. By ensuring liquidity, ECAs help its country's exporters enter into the competitive international markets with both products and financing, encouraging homecountry exports. Note that the risk mitigation and liquidity channels may not necessarily operate in silos and move in tandem. For instance, exporters with an ECA-issued export credit insurance not only insure themselves against delay/default of their foreign receivables (risk channel) but can also get financing from their banks by borrowing against the insurance policy (liquidity channel). ${ }^{12}$ Likewise, being financed by an ECA-backed direct loan not only ensures exporters/importers of enhanced fluidity (liquidity channel) but also, by transferring importers' debt obligation incurred in the purchase of ECA country's exports, protects exporters against defaulting importers or delayed import payments as well as provides flexibility to the importer in repaying the loan which further reduces the risk of default on repayment (risk channel). Alternatively, by assuming credit risk of private-financiers (risk channel) through refinancing guarantees or securitization, ECAs facilitate private financiers access to the funds they need for granting export credit that could then be passed on to the borrower (liquidity channel). Therefore, by responding to risk and inadequate liquidity in the trade finance market through various instruments, ECAs encourage its home country's exports. ${ }^{13}$

The magnitude of the potential positive impact of ECA financing on country exports, however, depends on a host of factors. For instance, destinations with a higher degree of information barriers and insecurity should benefit more strongly from ECA financing, independently of the industry structure (Egger and Url, 2006). Besides, industries that produce capital goods which are sophisticated, expensive, and involve long lead times with complex supply chains; and/or industries that demand a greater external financial dependence because of continuous investments requirements, large gestation periods, longer cash harvest periods, high R\&D, or high working capital, should benefit more strongly from ECA financing, particularly in counter-cyclical periods. This is because if demand dries up as a result of a financial failure or other types of globalization shock, there is a risk that the production losses will be permanent. ${ }^{14}$ In such cases, ECAs provide with necessary trade finance thereby preventing export and trade flow declines.

While ECAs' ability to complement risk with liquidity cannot be refuted, there are also a number

\footnotetext{
${ }^{12}$ Payment default/delay can happen for a number of reasons such as the borrower becoming insolvent, adverse measures taken by foreign governments or warlike events arise, among others.

${ }^{13}$ While there appears to be no literature that attempts to identify when and which form of ECA-backed trade financing instruments is used, there are such studies on bank-intermediated trade finance instruments (see Auboin and Engemann (2013) for a review).

${ }^{14} \mathrm{http}$ ://www.exim.gov/news/archives/speeches/us-exports-competitiveness-and-export-importbank-united-states.
} 
of factors which may eliminate or even reverse any export-enhancing benefits of ECA financing. ${ }^{15}$ For instance, because of government mandate or strategic objective ECAs may reallocate capital that would have been put into other uses. ${ }^{16}$ Unless reallocation of resources addresses market failure, economic efficiency may be lost. By taking resources from general economic uses and putting them to less-efficient uses, the bank creates distortions in the economy and imposes opportunity costs that are probably higher than the value-added generated from ECA intervention. Besides, ECAs may understate the economic costs of export financing by assuming that they have special insights or access to information which private financiers do not have and hence are in a better position to evaluate the creditworthiness of a transaction. ${ }^{17}$ As a result, ECAs may miscalculate the risk associated in cross-border activities, create a systematic bias for ECA financing, and crowd out private financiers who would be better able to lend on terms that reflect the market value and risk of projects. At best, distortive allocations may not generate additional exports as expected; at worst, the mercantilistic interventionism by ECAs may actually reduce exports.

It can therefore be derived that while ECA financing can affect aggregate exports via its impact on the cost to trade or the demand for ECA country's exports, the actual net effect is subject to empirical findings. In what follows, we use a modified gravity model to estimate the reduced-form net effect of ECA financing, and the estimation stands open to empirical irregularities which may influence the effect in various ways.

\section{Empirical Methodology}

Based on the theoretical underpinning of the gravity model of trade (e.g. Anderson and van Wincoop, 2003), market clearance and general equilibrium imply that bilateral trade between countries can be expressed as

$$
X_{i j k t}=e^{f\left(S_{j k t}\right)} E_{j k t}\left(\frac{Y_{i k t}}{Y_{k t}}\right)\left(\frac{\tau_{i j k t}}{P_{i k t} P_{j k t}}\right)^{1-\sigma_{k}},
$$

where exports of good $k$ from country $i$ to country $j$ in year $t, X_{i j k t}$, depend on a range of factors: country $j$ 's expenditure on $k$ in $t, E_{j k t}$; an adjustment factor $e^{f(\cdot)}$ which is a function of US EXIM support $S_{j k t}$ for importing country $j$ on sector $k$ in year $t$; the share of country $i$ in the world production of $k$ in $t, \frac{Y_{i k t}}{Y_{k t}}$; bilateral trade costs $\tau_{i j k t}$; and multilateral resistance terms $P_{i k t} P_{j k t}$. The parameter $\sigma_{k}$, which is assumed to be greater than one, is the elasticity of substitution specific to good $k$ and common across countries. Note that the adjustment factor $e^{f(\cdot)}$ broadly accommodates the aforementioned various influencing channels of EXIM financing on exports, and is thus intended to capture the reduced-form net effect of US EXIM support.

\footnotetext{
${ }^{15}$ The understanding of potential drawback of ECA intervention has been drawn from James (2011).

${ }^{16}$ The US EXIM Bank is one such example where congressional mandate/strategic objective may govern or define its credit authorization portfolio.

${ }^{17}$ Vanessa Weaver, a member of the Board of Directors of the US EXIM Bank, was quoted saying that while private financial institutions do not have enough information to assess which transactions are creditworthy, the Bank personnel can go in to a minister of finance or the president of a company and ask for accounting records that are audited under IAS rules thereby ensuring the required push for reforms and the kind of structures that are needed. See Weaver (2002).
} 
Taking natural logarithms of the both sides of (1) and setting $i=U S$ gives

$$
\ln X_{j k t}^{U S}=f\left(S_{j k t}\right)+\ln E_{j k t}+\ln \left(\frac{Y_{k t}^{U S}}{Y_{k t}}\right)+\left(1-\sigma_{k}\right)\left[\ln \tau_{j k t}^{U S}-\left(\ln P_{k t}^{U S}+\ln P_{j k t}\right)\right] .
$$

A challenge in practice with the estimation of the above specification is that it is difficult to find data for all the variables $E_{j k t}, \frac{Y_{k t}^{U S}}{Y_{k t}}, \tau_{j k t}^{U S}, P_{k t}^{U S}$, and $P_{j k t}$ that are time variant for disaggregated industries (NAICS4 level). ${ }^{18}$ To overcome this difficulty, we make assumptions that the values of $E_{j k t}$ and $\frac{Y_{k t}^{U S}}{Y_{k t}}$ are time functions of their base-year values, and the variables $\tau_{j k t}^{U S}, P_{k t}^{U S}$, and $P_{j k t}$ are proportional to their country-level counterparts with the proportions remaining stable over time:

$$
\begin{aligned}
E_{j k t} & \equiv e^{\delta_{t}} E_{j k}, \\
Y_{k t}^{U S} / Y_{k t} & \equiv e^{\theta_{t}} Y_{k}^{U S} / Y_{k}, \\
\tau_{j k t}^{U S} & \equiv e^{\lambda_{k}} \tau_{j t}^{U S}, \\
P_{k t}^{U S} & \equiv e^{\gamma_{k}} P_{t}^{U S}, \\
P_{j k t} & \equiv e^{\mu_{k}} P_{j t} .
\end{aligned}
$$

Now inserting (3) into (2) and further assuming the linearity of $f(\cdot)$ (i.e. $\left.f\left(S_{j k t}\right)=\alpha S_{j k t}\right)$ and the constancy of the elasticity of substitution between all goods (i.e. $\sigma_{k}=\sigma$ ), we have

$$
\begin{aligned}
\ln X_{j k t}^{U S}= & \alpha S_{j k t}+\ln E_{j k}+\ln \left(\frac{Y_{k}^{U S}}{Y_{k}}\right)+(1-\sigma)\left[\ln \tau_{j t}^{U S}-\left(\ln P_{t}^{U S}+\ln P_{j t}\right)\right] \\
& +\delta_{t}+\theta_{t}+(1-\sigma)\left(\lambda_{j k}-\gamma_{k}-\mu_{k}\right) .
\end{aligned}
$$

Merging overlapping parameters, we have the following equation for empirical estimation:

$$
\begin{aligned}
\ln X_{j k t}^{U S}= & \alpha S_{j k t}+(1-\sigma)\left[\ln \tau_{j t}^{U S}-\left(\ln P_{t}^{U S}+\ln P_{j t}\right)\right] \\
& +\phi_{t}+\eta_{j k}+\mathbf{Z}_{j k t} \boldsymbol{\Gamma}+\epsilon_{j k t},
\end{aligned}
$$

where the vector $\mathbf{Z}_{j k t}$ contains additional controls, $\phi_{t}$ captures all unobserved time-specific factors, $\eta_{j k}$ absorbs all country-industry-specific factors including the time-invariant variable $E_{j k}$, and the error term $\epsilon_{j k t}$ represents the white noise of the model.

As the standard practice in the empirical gravity literature, we assume bilateral trade costs $\tau_{j, t}^{U S}$ to be a function of a number of geographical, cultural, and institutional factors:

$$
\begin{aligned}
\tau_{j t}^{U S} \equiv & \exp \left(\rho_{1} d i s t_{j}^{U S}+\rho_{2} l_{a n g}^{U S}+\rho_{3} \operatorname{contig}_{j}^{U S}+\rho_{4} l e g_{j}^{U S}+\rho_{5} \operatorname{curr}_{j}^{U S}+\rho_{6} \operatorname{col}_{j}^{U S}\right. \\
& \left.+\rho_{7} w t o_{j t}^{U S}+\rho_{8} r t a_{j t}^{U S}\right),
\end{aligned}
$$

where $d i s t_{j}^{U S}$ is the logged geographical distance between country $j$ and the US weighted by the

\footnotetext{
${ }^{18}$ Despite a large number of missing records, the UN-INDSTAT database provides data on industrial output for 2-digit ISIC sectors of many countries, but not on price. The same applies to OECE-STAN database which covers even less countries. Data on country-industry-year specific demand is also unavailable.
} 
population of countries, $l a n g_{j}^{U S}$ is a dummy which takes on the value of one if country $j$ has the same official language (i.e. English) as the US and zero otherwise, contig $g_{j}^{U S}$ is a dummy for sharing the border with the US, $l e g_{j}^{U S}$ is a dummy for having the same legal origin as the US, $c u r r{ }_{j}^{U S}$ is a dummy for sharing the same official currency (i.e. the US dollar) as the US, $w t o_{j t}^{U S}$ the dummy for the partner country being a member of GATT/WTO as is the US, and $r t a_{j t}^{U S}$ the dummy for being in a common regional free trade agreement with the US.

Following Baier and Bergstrand (2009) and Berger et al. (2013), the multilateral resistance terms, $\ln P_{t}^{U S}+\ln P_{j t}$, are approximated by a first-order log-linear expansion of the nonlinear price equation system in Anderson and van Wincoop (2003). Specifically, it is shown that under the assumption of symmetry of bilateral trade costs, the multilateral resistance terms can be expressed as GDP-weighted average trade costs:

$$
\ln P_{t}^{U S}+\ln P_{j t}=\sum_{l=1}^{N} \omega_{l, t} \ln \tau_{j, l, t}+\sum_{l=1}^{N} \omega_{l t} \ln \tau_{l t}^{U S}+\sum_{l=1}^{N} \sum_{m=1}^{N} \omega_{l t} \omega_{m t} \ln \tau_{k m t},
$$

where $\omega_{l t} \equiv Y_{l t} / Y_{t}$ is the share of country $l$ in world GDP.

Plugging (6) into (7) gives a function of the multilateral resistance terms as a linear combination of observable components of trade costs as in (6):

$$
\begin{aligned}
\ln P_{t}^{U S}+\ln P_{j, t}= & \rho_{1} Q_{j}^{\text {dist }}+\rho_{2} Q_{j}^{\text {lang }}+\rho_{3} Q_{j}^{\text {contig }}+\rho_{4} Q_{j}^{\text {leg }}+\rho_{5} Q_{j}^{\text {curr }}+\rho_{6} Q_{j}^{\text {col }} \\
& +\rho_{7} Q_{j t}^{\text {wto }}+\rho_{8} Q_{j t}^{r t a},
\end{aligned}
$$

where

$$
\begin{aligned}
& Q_{j}^{s} \equiv \sum_{l=1}^{N} \omega_{l t} s_{j l}+\sum_{l=1}^{N} \omega_{l t} s_{l}^{U S}+\sum_{l=1}^{N} \sum_{m=1}^{N} \omega_{l t} \omega_{m t} s_{k m}, \\
& \text { for } s=\text { dist, lang, contig, leg, curr, col } \\
& Q_{j t}^{s} \equiv \sum_{l=1}^{N} \omega_{l t} s_{j l t}+\sum_{l=1}^{N} \omega_{l t} s_{l t}^{U S}+\sum_{l=1}^{N} \sum_{m=1}^{N} \omega_{l, t} \omega_{m t} s_{k m t}, \text { for } s=\text { wto, rta } .
\end{aligned}
$$

Therefore we can now control for trade costs and multilateral resistance terms jointly using the same set of observable variables:

$$
\begin{aligned}
\ln \tau_{j, t}^{U S}-\left(\ln P_{t}^{U S}+\ln P_{j, t}\right)= & \rho_{1}\left(\text { dist }_{j}^{U S}-Q_{j}^{\text {dist }}\right)+\rho_{2}\left(\operatorname{lang}_{j}^{U S}-Q_{j}^{\text {lang }}\right) \\
& +\rho_{3}\left(\operatorname{contig}_{j}^{U S}-Q_{j}^{\text {contig }}\right)+\rho_{4}\left(\operatorname{leg}_{j}^{U S}-Q_{j}^{\text {leg }}\right) \\
& +\rho_{5}\left(\operatorname{curr}_{j}^{U S}-Q_{j}^{c u r r}\right)+\rho_{6}\left(\operatorname{col}_{j}^{U S}-Q_{j}^{c o l}\right) \\
& +\rho_{7}\left(w t o_{j t}^{U S}-Q_{j t}^{w t o}\right)+\rho_{8}\left(r t a_{j t}^{U S}-Q_{j t}^{r t a}\right) .
\end{aligned}
$$




\section{Background of the US EXIM Bank}

Founded in 1934, the US EXIM Bank is the official export credit agency of the United States. It operates as an independent, self-sustaining, and wholly owned corporation of the US government. Its mission is to create and sustain US jobs by financing and facilitating the exports of US goods and services, providing competitive export financing, and ensuring a level playing field for US goods and services in the global marketplace. The Bank in exercising its functions, supplements and encourages, and not competes, with private financiers. As a matter of fact, the Bank is encouraged to consider the need to involve private financiers while determining whether to provide support for a transaction. This is evident in the fact that about $98 \%$ of the Bank's transactions include a partnering private financial entity (US EXIM Bank, 2014). While the Bank assumes credit and country risk that private financiers are unwilling or unable to accept by providing financing at terms competitive with foreign ECAs, it must balance this risk by ensuring reasonable assurance of repayment for its credit authorization. ${ }^{19}$

Given congressional mandate or its own strategic objective, the Bank supports certain types of exports. For instance, on the one hand, the Bank is mandated to make available not less than $25 \%$ of its authorized capital to small and medium enterprises, and at the same time it must promote greater financing to projects that focus on renewable energy and sub-Saharan African region. ${ }^{20}$ On the other hand, the Bank also strategically provides competitive financing to certain industries perceived with high potential for US export growth which comprise of agribusiness, aircraft and avionics, satellites, mining, oil and gas development, and power generation involving renewable energy. Besides industries, the Bank strategically targets nine key markets which it identifies as high potential emerging economies: Brazil, Colombia, Mexico, Turkey, South Africa, Nigeria, India, Indonesia, and Vietnam (US EXIM Bank, 2013b).

Internationally, the Bank abides by the disciplines laid out under the OECD Arrangement on Officially Supported Export Credits. ${ }^{21}$ The Arrangement is a "Gentlemen's Agreement" negotiated by the participants to the Arrangement. ${ }^{22}$

\footnotetext{
${ }^{19}$ Section 2(b)(1)(B), the Charter of the Export-Import Bank of the United States (the Charter hereafter), updated February $29,2016$.

${ }^{20}$ The Bank does not have a quantitative target to promote the exports of goods and services related to renewable energy sources, and to promote financing to sub-Saharan Africa. See in the Charter Section 2(b)(1)(E)(v) for small business, Section 2(b)(1)(K) for renewable energy, and Section 2(b)(9)(A) for Sub-Saharan Africa.

${ }^{21}$ The main purpose of the Arrangement is to provide a framework for the orderly use of government-backed export financing (within the participating countries), with the goal of encouraging competition among exporters based on quality and price of goods and services rather than on the most favorable government-backed financing terms and conditions. The financing terms and conditions could be related to minimum interest rates, risk fees, and maximum repayment terms. The OECD views the Arrangement as "rules" defining constraints on members' lending activity.

${ }^{22}$ The participants to the OECD Arrangement currently are: Australia, Canada, the EU, Japan, South Korea, New Zealand, Norway, Switzerland and the United States (for the purpose of this paper, countries in the EU are taken from https://www.gov.uk/eu-eea.). Brazil is a participant to the Sector Undertaking On Export Credits For Civil Aircraft. Information on participating countries has been gathered from the Agreement on Officially Supported Export Credits, February 1, 2016, TAD/PG(2016)1.
} 


\section{Data and Descriptive Statistics}

The US EXIM support data used in this study is drawn from the annual accounting reports of the Bank which is made available under the Open Government Directive. ${ }^{23}$ It contains transactional information on all authorizations that has been approved or denied by the EXIM Board of Directors from 2007 through 2013. ${ }^{24}$ Transactional information includes authorized amount that has been approved including approved amount to assist small American businesses, financing program (direct loans, loan guarantees or export credit insurance), industry classification of the product (6-digit NAICS or 4-digit SIC code), country of the foreign buyer, among others.

To address our research question, we map the Bank's transactional data to the US exports data extracted from UN COMTRADE. ${ }^{25}$ Using concordances from US Census Bureau and US Bureau of Economic Analysis, we aggregate the industry classification to 4-digit IO/NAICS sectors. After cleaning the data, our sample comprises of 148,708 observations resulting from a three dimensional panel of 226 countries, 94 industries, and 7 years spanning from 2007 to 2013. On the one hand, only $11 \%$ of the country-industry-year observations records no imports from the US. The remaining $89 \%$ have imports from the US at least once across all the 7 years, $62 \%$ imported from the US for all 7 years in the dataset. On the other hand, $96 \%$ of the country-industry-year observations received no EXIM authorization. The remaining $4 \%$ report to having been authorized by the Bank at least once across the 7 years, while only $0.13 \%$ report to having been authorized by the Bank for all the years in the sample period.

Figure 1 reveals, at both country and industry levels, a positive correlation between the total value of the Bank's authorization portfolio and US exports, thus backing the Bank's assertion of supporting American exporters by equipping them with financing tools necessary to compete for global sales.

Nevertheless, Tables 1 and 2 reveal the skewed distribution of EXIM authorization across countries and industries where the Bank does not necessarily authorize its available funds to those countries and industries that dominate US exports. For instance, India received a maximum $10.96 \%$ share of the Bank's portfolio followed by Saudi Arabia at $10.55 \%$. However, total exports to India and Saudi Arabia accounted for only $1.46 \%$ and $1.08 \%$ share of total US exports as against the maximum $20.76 \%$ share of total US exports to Canada who received only $1.60 \%$ share in the Bank's portfolio. In a similar vein, while aerospace products and parts (NAICS 3364) received a maximum $49.09 \%$ share of the Bank's portfolio, its exports accounted for only $2.19 \%$ of total US exports as opposed to the maximum $6.22 \%$ share of petroleum and coal products (NAICS 3240) exports that received only

\footnotetext{
${ }^{23}$ Data can be accessed at http://www.exim.gov/open-government-directive.

${ }^{24}$ The dataset reports only 2 transactions, one from each fiscal year 2012 and 2013, where the EXIM Board of Directors denied authorization. The two transactions amounted to US $\$ 61,465,615$ representing a mere $0.11 \%$ of the total authorizations approved for the fiscal year 2012 and 2013. We exclude the two denied transactions from the dataset. The resulting dataset used in the paper comprises of all authorizations approved by the EXIM Board of Directors from 2007 through 2013.

${ }^{25}$ The Bank's transactional data fail to provide information on US exports. We, therefore, use available information on the country of foreign buyer, industry classification of the product, and the year of authorization, to aggregate transactions at the country-industry-time level. Much of the transactional information is lost in the process of transforming disaggregated transaction level data to aggregated country-industry-time level data. To the transformed country-industry-time level dataset, we then append the US exports data from UN COMTRADE.
} 

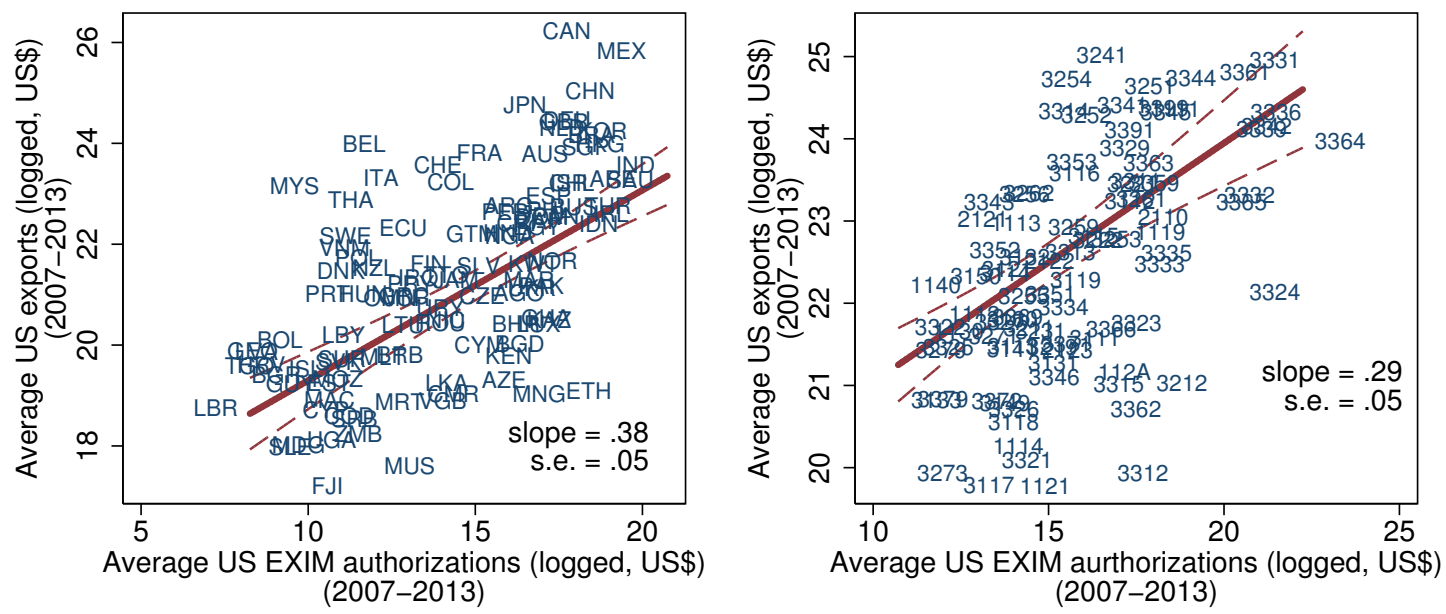

Fig. 1. US EXIM authorization and US exports by country and industry. The left panel shows the correlation between the log values of US exports and US EXIM authorization, both in US\$ and taken as averages of the period 2007-2013, for all country destinations. The right panel shows the correlation between the log values of US exports and US EXIM authorization, both in US\$ and taken as averages of the period 2007-2013, for all US 4-digit NAICS industries. The solid straight lines are the fitted linear trends, and the surrounding dashed lines give the $95 \%$ confidence intervals of the estimated linear trends.

$0.06 \%$ share in the Bank's authorization.

Table 3 shows that there is a negative correlation between what the Bank authorizes to a region in total and what it authorizes to small businesses for that particular region. For instance, for the period 2007 through 2013, Asian region received the highest share in the Bank's total authorization portfolio of loans, guarantees and insurance at $34.4 \%$, of which only $2 \%$ was authorized to small businesses. On the contrary, for the same period, Caribbean region received the lowest share in the Bank's total authorization portfolio at $1.1 \%$, of which, however, $24.7 \%$ was authorized to small businesses. It should be noted that on a global scale the Bank's authorization to small businesses ranges from 5\% to $11 \%$ for the period 2007 through 2013, which is well below the mandated authorization to small businesses at $20 \% .^{26}$

The definitions and summary statistics of the main variables of this research are contained in Table 4. Not surprisingly, the variables for exports and EXIM authorizations have large standard deviations relative to their means as a result of the highly skewed distributions as seen from above. The gravity variables contain sufficient variations representing a wide spectrum of characteristics of US trade partners in the data. The four standardized foreign ECA competition measures show varying degrees of ECA competition US exporters face in foreign markets (see Section 6.3 for the details about the construction of these measures).

\footnotetext{
${ }^{26}$ See Section 635(b)(1)(E)(v) of the US Code Title 12 "Banks and Banking". Note that this threshold was raised to 25\% in December 2015; see Section 2(b)(1)(E)(v), the Charter.
} 
Table 1. Top 20 US EXIM supported destinations and US export markets

\begin{tabular}{lrlr}
\hline \multicolumn{2}{c}{ (A) US EXIM support recipients } & \multicolumn{2}{c}{ (B) US export destinations } \\
Name & Share $(\%)$ & Name & Share (\%) \\
\hline India & 10.96 & Canada & 20.76 \\
Saudi Arabia & 10.55 & Mexico & 14.08 \\
Mexico & 8.39 & China & 6.39 \\
United Arab Emirates & 6.25 & Japan & 4.84 \\
Turkey & 5.37 & Germany & 3.55 \\
Ireland & 4.96 & United Kingdom & 3.44 \\
Rep. of Korea & 4.73 & Netherlands & 3.03 \\
China, Hong Kong SAR & 4.40 & Rep. of Korea & 2.86 \\
Indonesia & 3.62 & Brazil & 2.64 \\
Brazil & 3.29 & Belgium & 2.21 \\
China & 3.28 & China, Hong Kong SAR & 2.21 \\
Ethiopia & 2.96 & Singapore & 2.10 \\
Singapore & 2.81 & France & 1.86 \\
Russian Federation & 1.95 & Australia & 1.81 \\
Chile & 1.78 & Switzerland & 1.48 \\
Germany & 1.61 & India & 1.46 \\
Canada & 1.60 & Italy & 1.12 \\
United Kingdom & 1.49 & United Arab Emirates & 1.10 \\
Israel & 1.46 & Saudi Arabia & 1.08 \\
Netherlands & 1.34 & Colombia & 1.04 \\
\hline
\end{tabular}

Note. This table reports the top 20 markets, ranked by their shares in US total EXIM authorization and exports (2007-2013) respectively.

Table 2. Top 20 US EXIM supported industries and US export industries

\begin{tabular}{lrlr}
\hline \multicolumn{2}{c}{ (A) US EXIM support industries } & & \multicolumn{2}{c}{ (B) US export industries } \\
\cline { 5 - 5 } Name & Share $(\%)$ & Name & Share $(\%)$ \\
\hline Aerospace products & 49.09 & & Petroleum and coal products \\
Engines and turbines & 7.86 & Agriculture and construction mach. & 6.22 \\
Agriculture and construction mach. & 7.65 & Motor vehicles & 5.84 \\
Boilers, tanks, and shipping containers & 7.62 & Electronic components & 4.07 \\
Communications equipment & 6.02 & Pharmaceuticals and medicines & 4.68 \\
Other general purpose mach. & 5.23 & Basic chemicals & 4.27 \\
Industrial machinery & 3.72 & Computer equipment & 3.38 \\
Motor vehicles & 3.27 & Misc, manufactured commodities & 3.29 \\
Railroad rolling stock & 2.95 & Oilseeds and grains & 3.21 \\
Electronic components & 0.7 & Nonferrous metal & 3.15 \\
Wood products & 0.54 & Electronic instruments & 3.12 \\
Oilseeds and grains & 0.44 & Engines and turbines & 3.11 \\
Metalworking machinery & 0.35 & Resin, rubber, and artificial fibers & 2.98 \\
Electronic instruments & 0.34 & Communications equipment & 2.64 \\
Misc. manufactured commodities & 0.32 & Other general purpose mach. & 2.52 \\
Oil and gas extraction & 0.32 & Medical equipment and supplies & 2.51 \\
Other agricultural products & 0.29 & Aerospace products and parts & 2.19 \\
Commercial and service mach. & 0.29 & Other fabricated metal products & 2.01 \\
Other electrical equipment & 0.24 & Electrical equipment & 1.69 \\
Basic chemicals & 0.22 & Motor vehicle parts & 1.68 \\
\hline
\end{tabular}

Note. This table reports the top 20 industries (4-digit NAICS), ranked by their shares in US total EXIM authorization and exports (2007-2013) respectively. 


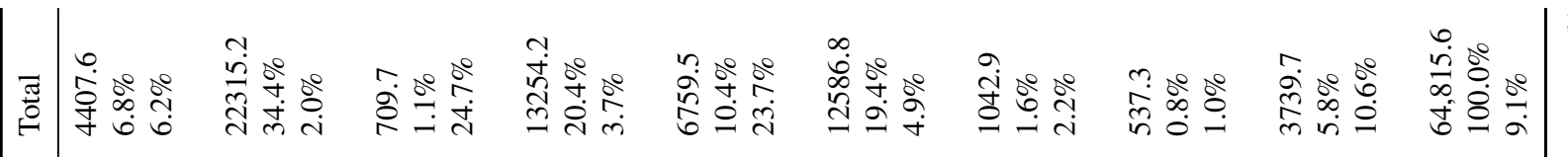

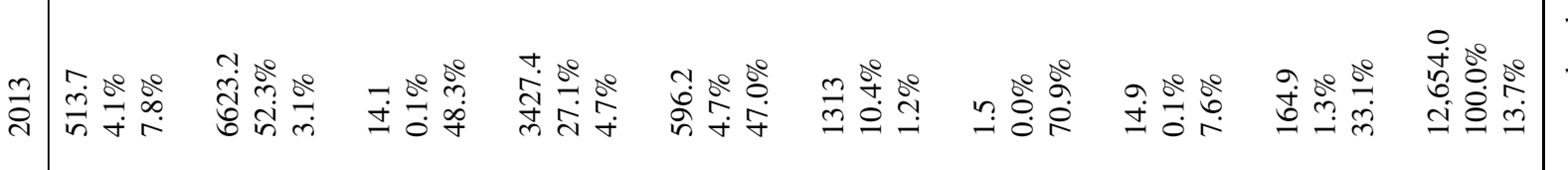

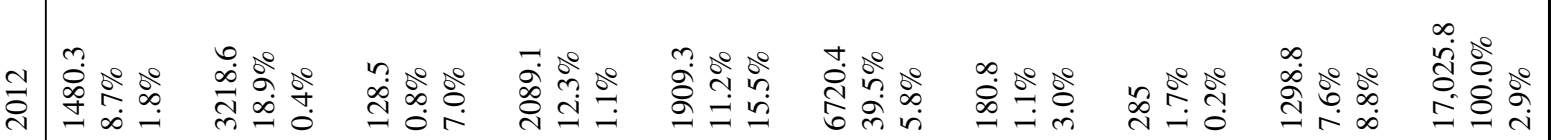

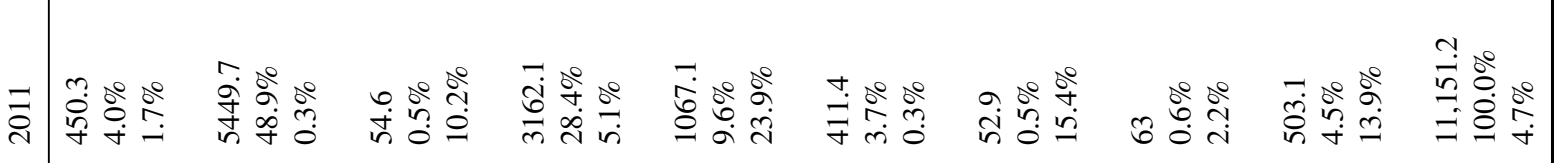

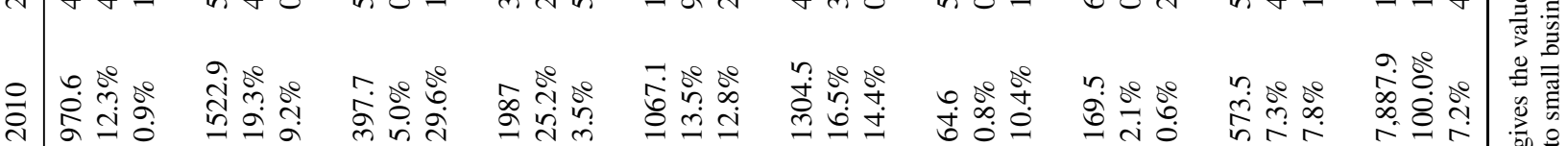

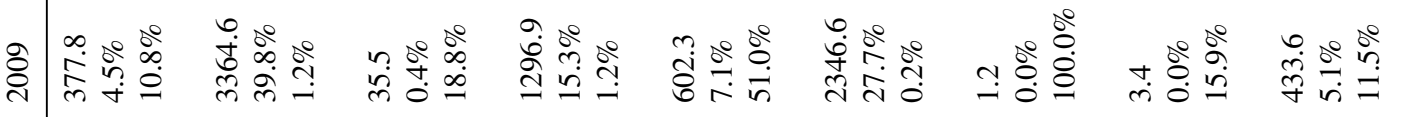
. i.

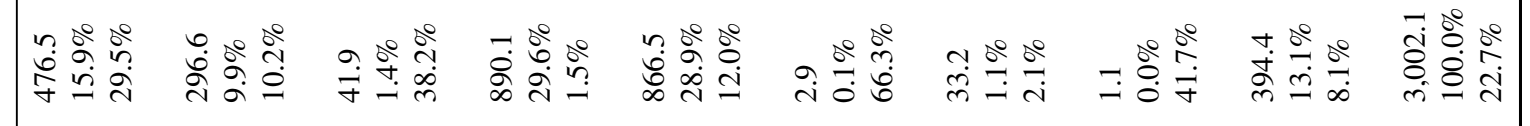

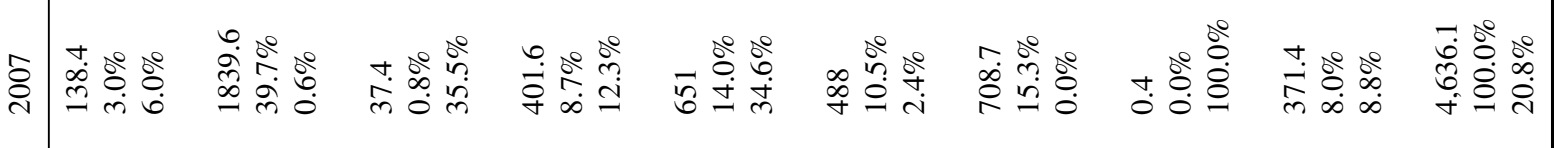

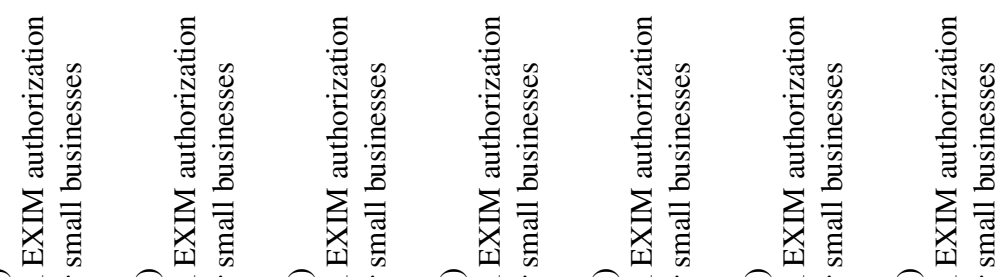

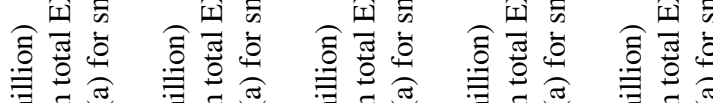

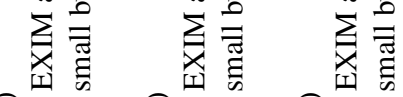

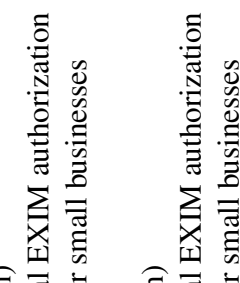

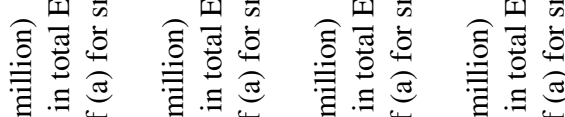

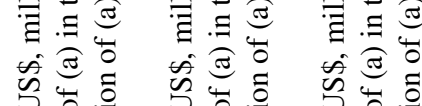

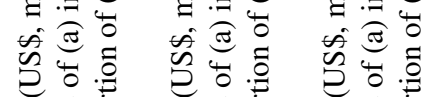

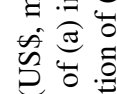

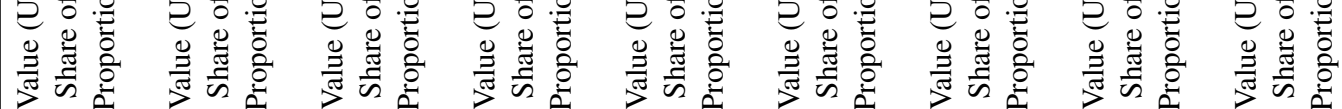

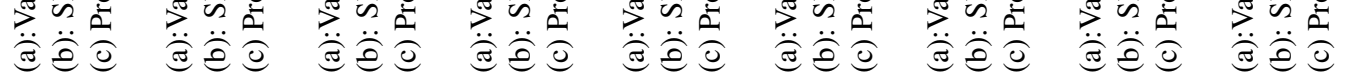

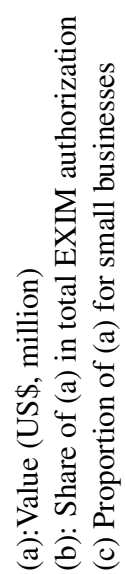

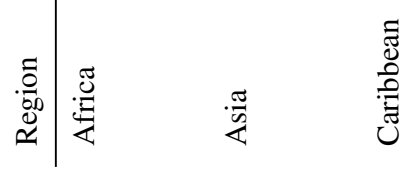
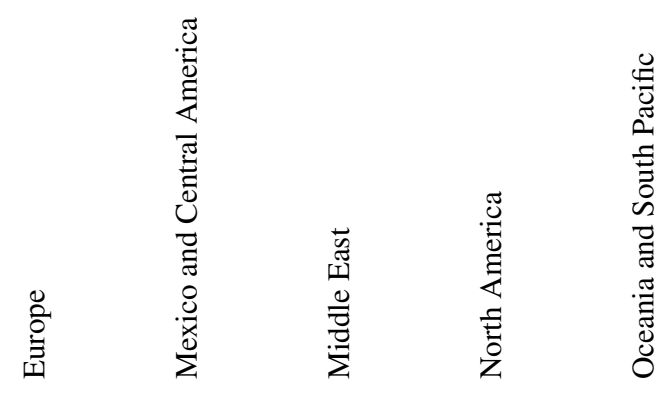

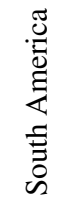




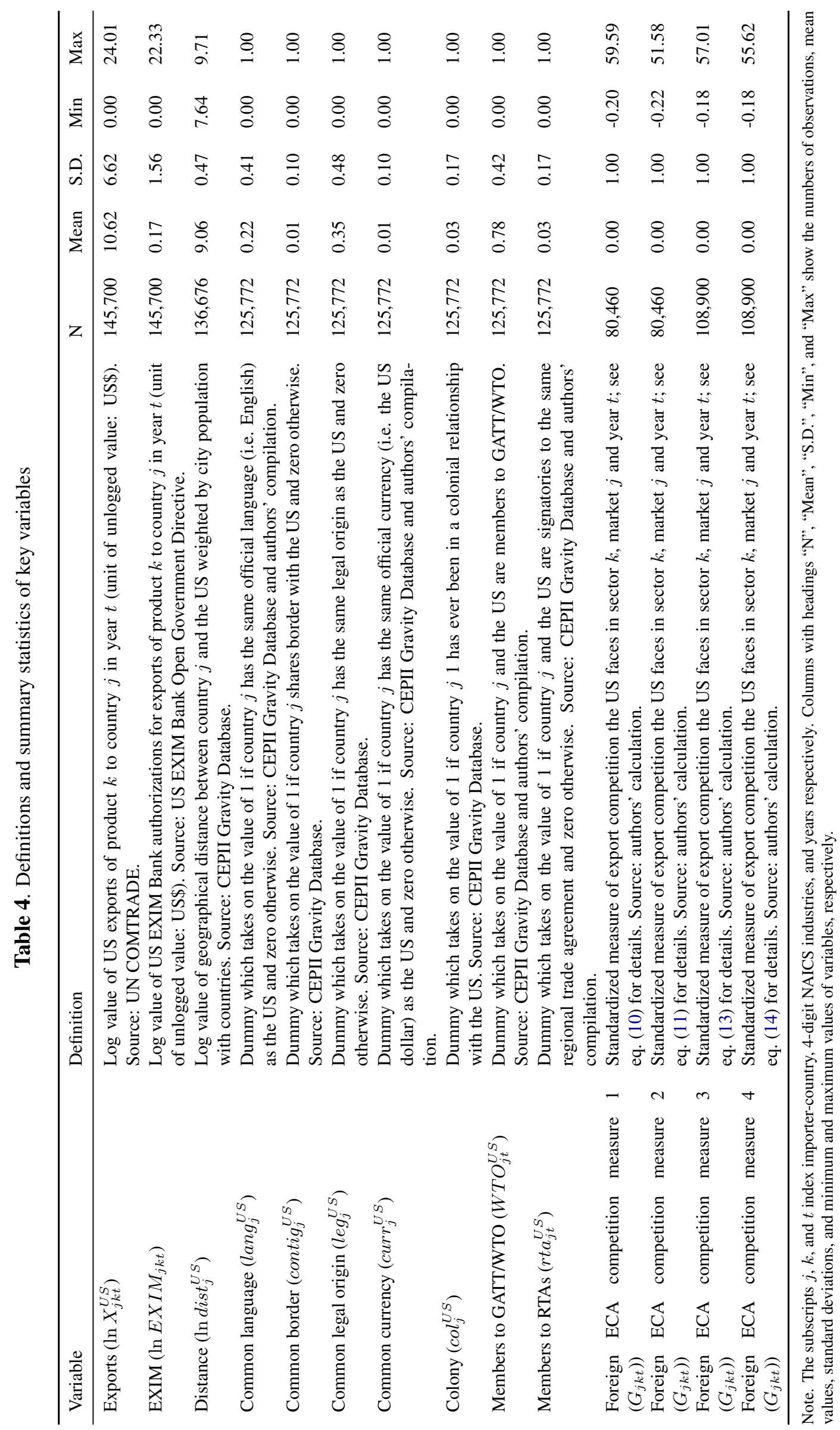




\section{Results}

\subsection{Baseline results}

We now turn to our formal regression analysis, looking into the estimated results of eq. (5) in various forms. Note that since our data is rectangularized (i.e. expanded so that all possible countryindustry-year combinations exist) to facilitate gravity analysis, a great number of zeros are created. In our baseline regressions, we adopt three approaches to address the issue of the excessive number of zeros. First, we follow the common practice of adding one US dollar to both export and EXIM authorization values before taking logs so that all observations are kept in log transformation. Second, we replace the continuous EXIM authorization measure with an EXIM authorization indicator which takes on the value of one if a country-industry-year observation receives positive EXIM authorization and zero otherwise, which allows us to estimate the effect of receiving any positive EXIM authorization as a whole. Third, reported in Appendix A we use Poisson estimations to avoid adding one to the dependent variable (i.e. exports) as suggested by (e.g. Silva and Tenreyro, 2006). ${ }^{27}$

A potential bias in the estimation comes from the "selection" of projects due to the congressional mandate or strategic financing objective. In particular, if firm size is positively correlated with exports (e.g. Bernard and Jensen, 1995), congressional mandate to provide a proportion of EXIM authorized capital to small and medium enterprises (SMEs) could lead to a downward bias in the estimated EXIM effect. To address this concern, first we control for the employment share of SMEs in each NAICS industry using data from the US Census Bureau. ${ }^{28}$ Second, the inclusion of country-industry fixed effects ensures that any influences from unobserved factors specific at these levels are ruled out, in particular those factors, such as geopolitical preference, that would affect the country-industry preferences in EXIM financing decisions. Lastly, by introducing time dummies, time effects common to all industries and markets are netted out.

The baseline results are reported in Table 5. We find that the coefficient on the contemporaneous EXIM authorization variable, whether continuous or binary, is negative but statistically insignificant from zero when stronger specifications of fixed effects (country-industry fixed effects) are imposed in columns 2-3 and 5-6. This implies that in a given year, EXIM authorizations do not have a sizable impact on US exports with its partner countries. The sign and magnitude of the estimated elasticity of EXIM authorizations with respect to US exports stand in contrast to the positive and significant estimates found by Egger and Url (2006) for Austria, Moser et al. (2008) and Felbermayr and Yalcin (2013) for Germany, with magnitude in the range of 0.04-0.66. ${ }^{29}$ We also conduct Poisson regressions and experiment on the baseline specifications using the subsample of positive EXIM

\footnotetext{
${ }^{27}$ We only do this for the baseline specifications as the implementation of Poisson estimation on fuller models with many dummies requires extraordinarily large computational power which is beyond an ordinary workstation capacity.

${ }^{28} \mathrm{We}$ also try including the share of SMEs in the total number of firms in each NAICS industry, and the results remain almost identical. In addition, the exclusion of these SME share measures also does not impact the conclusions.

${ }^{29}$ In the view of the fact that differences in the export-promoting effects of German and Austrian ECAs could be for a number of reasons such as differences in management and operations, products and facilities they offer, to name a few, and that Egger and Url (2006), Moser et al. (2008) and Felbermayr and Yalcin (2013) do not explicitly attribute their results to any such specific factor, reference to their estimated impact is only representational and not comparative. Also see International Financial Consulting Ltd. (2012) and Hecker (1997) on differences across ECAs that make it difficult to compare the same.
} 
authorization observations only. Estimates shown in Table A1, Appendix A, are qualitatively in line with the above findings. For the ease of interpretation of elasticities, our preferred estimates in the rest of the analysis remain to be the continuous EXIM authorization variable.

Note that it is possible that EXIM authorization in a given year translates into exports in the following years for two reasons. First, because we measure EXIM support as total authorization, it often takes more than one year (especially for longer-term loans) for all the authorized funds to be disbursed for trade. Second, there may exist some time gap between the authorization and the actual availability of funds for use (Egger and Url, 2006; Moser et al., 2008). Therefore, to test whether EXIM authorization has an effect beyond the year of authorization, in columns 8-10 we introduce lagged EXIM authorization variables which take into account EXIM authorization in both present and past years. We find that the coefficient on the lagged EXIM authorization variable, whether continuous or binary, stay insignificant. This implies that there are no detectable time lag effects of EXIM authorization.

The above analysis consists of all industries which are treated equally in the regression. Nevertheless, it is evident in Table 2 that aerospace parts and products (NAICS 3364) enjoys the lion's share in the EXIM's financing portfolio, accounting for half of the Bank's authorization. If for other controlled factors this industry has a higher tendency of exports, it is then necessary to separate this particular industry from others in estimation as the inclusion of it may lead to upward bias in the EXIM effect. Consequently, estimates presented in Table 6 now show that EXIM authorization to sectors other than aerospace parts and products has a significant but very small positive effect on US export activities: we estimate an elasticity of 0.003 for the present-year effect (column 10), which suggests that an increase in EXIM authorization by $10 \%$ creates additional exports by $0.03 \%$ in the same year. If lags of EXIM authorization are accounted for, we find an increase in the magnitude of EXIM authorization effect in the range of 0.006 (column 11), suggesting that a $10 \%$ expansion in EXIM authorization generates a $0.06 \%$ increase in exports. To better grasp the economic meaning of the magnitude, we compute average elasticity. Country-industry average of EXIM authorization is about US\$20.5 million and the average US exports is about US\$74.3 million. ${ }^{30}$ Therefore, a $10 \%$ increase in the average annual EXIM authorization, which is US\$2.05 million $(20.5 \times 0.1)$, creates additional exports of US $\$ 2.23$ milion $(74.3 \times 0.03)$, which amounts to an economically relevant multiplier of $2.23 / 2.05=1.09$. A size of this multiplier means that every US $\$ 100$ of EXIM authorization to sectors other than aerospace products, creates US\$109 of additional US exports from these sectors as a whole. The size of this estimated multiplier is lower than those found for Germany at 1.7 (Moser et al., 2008) and Austria at 2.8 (Egger and Url, 2006).

It should also be noted that: (a) lags of EXIM authorization beyond two years, do not have an impact on US exports (column 12), and (b) the effect of EXIM authorization is greater for model with lags (column 11) when compared to models with contemporaneous effect (column 10). As we do not find evidence of export-promoting benefits arising from EXIM authorization to the aerospace parts and products sector (columns 1-6), the remaining analysis focuses on other sectors.

\footnotetext{
${ }^{30}$ The figures used to calculate elasticities in this section are based on the real term values corresponding to the relevant non-zero sub-samples in the dataset.
} 


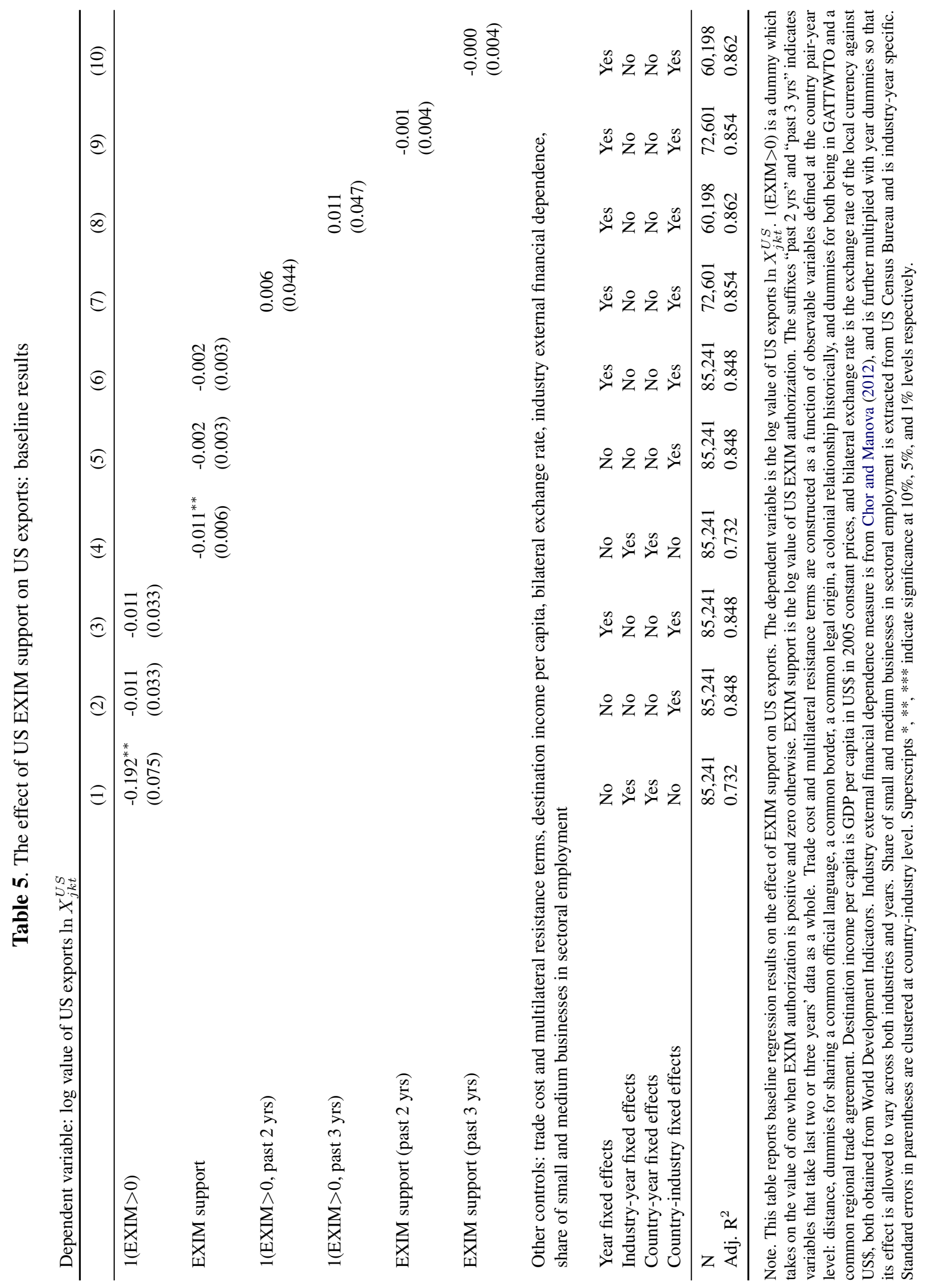




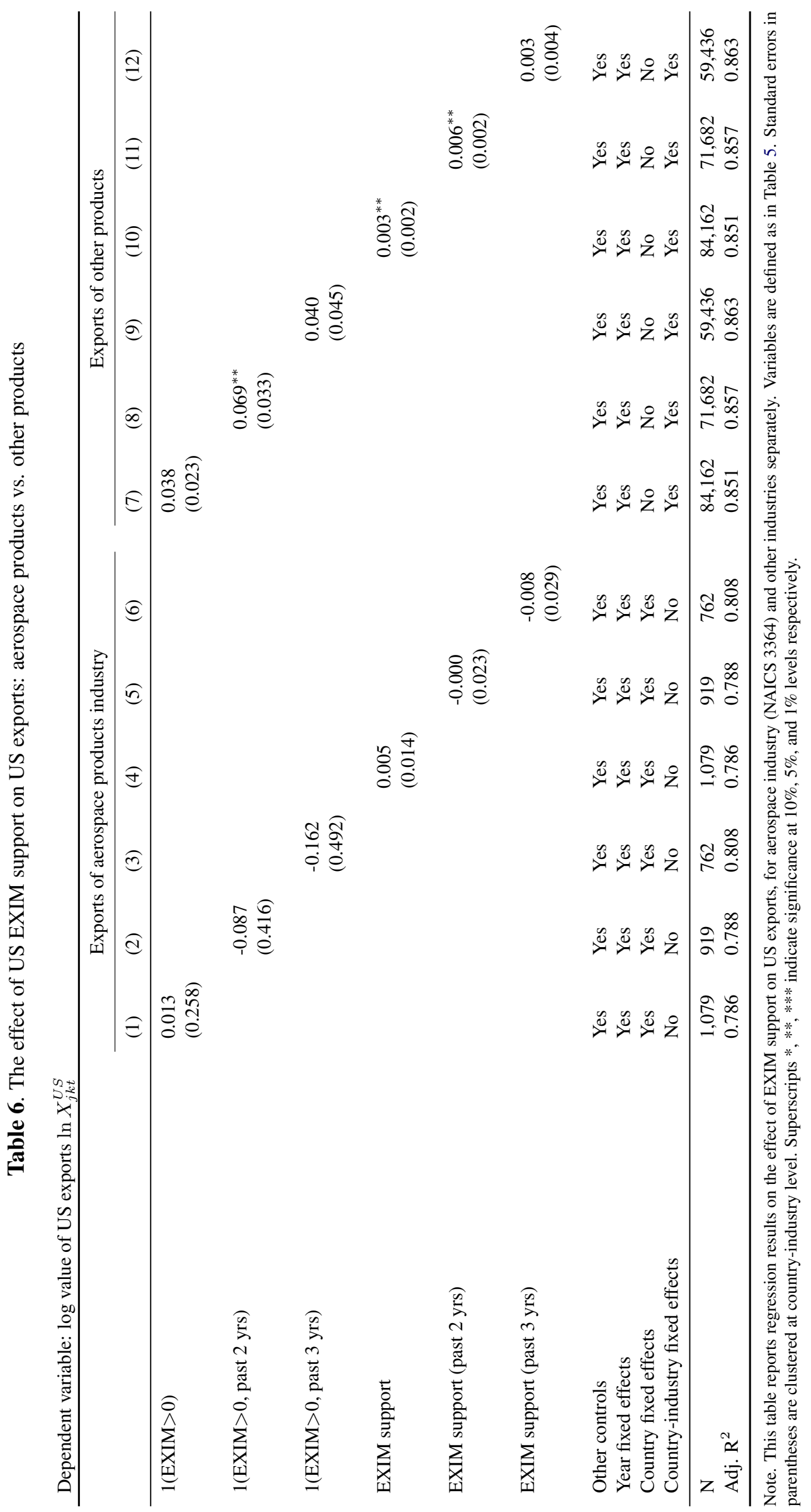




\subsection{EXIM financing to small businesses}

We now proceed to disentangle the export-promoting effect of EXIM authorization across American companies of different sizes. This is particularly motivated by the rising debate around the need to provide EXIM support for small exporting businesses and its potential impact on their exports. Proponents, on the one hand, argue that the value of small businesses' exports has grown markedly in recent years because the Bank shoulders some of the risks of international deals and provides private-market alternative financing. For instance, John Murphy, the senior vice president of the US Chamber of Commerce, argues that buyers overseas increasingly expect vendors to offer financing. In such a case, without the Bank, many US small businesses would be unable to extend terms to foreign buyers and would have to ask for cash-in-advance. ${ }^{31}$ Moreover, commercial banks often refuse to accept foreign receivables as collateral for a loan without the Bank's guarantee. ${ }^{32}$ Opponents, on the other hand, argue that the significant growth of small businesses' exports is unlikely to have been driven by EXIM support as the vast majority of small businesses do not get any EXIM financial assistance. For instance, according to USITC (2010), between 1997 and 2007 the value of exports per small and medium-size business increased by $80 \%$, yet the Bank supported only $0.04 \%$ of small business establishments in 2007 (de Rugy, 2014).

Taking these contradictory observations to the data, and estimating eq. (5) for small and nonsmall businesses groups, the estimates presented in columns 1-3 in Table 7 show that EXIM authorization to small businesses does not have an impact on their exports. On the contrary, it is the businesses that are not classified as small by the Bank that witness a positive impact of EXIM authorization on their exports with an upto two-year lag.

These results suggest that EXIM authorization to small exporting businesses does not serve as a strong engine for US exports. Although transactions for small business exporters increased from $85.6 \%$ of the total number of transactions in 2007 to nearly $90 \%$ in 2013, representing the highest number ever for small businesses (US EXIM Bank, 2007, 2013a), our interpretation here is that EXIM authorization to small businesses does not generate dollar value to the export kitty of the US and EXIM support is not a lifeline to small businesses' exports as claimed by the EXIM Bank proponents.

To summarize, while the baseline results (Table 5) show that EXIM authorization does not have a contemporaneous or lagged export-promoting effect, we do find that EXIM authorization to sectors other than aerospace products has a positive effect on US exports (Table 6). Moreover, the positive effect is mainly driven by the Bank's authorization to American companies that are not classified as small by the Bank (Table 7) .

\subsection{Foreign ECA competition}

A common argument around the EXIM Bank is that without its export financing, foreign companies would turn away from American goods and buy products from exporters whose countries offer

\footnotetext{
${ }^{31}$ http://thehill.com/blogs/congress-blog/economy-budget/246347-the-arguments-for-ex-im-noone-can-rebut.

${ }^{32} \mathrm{http}$ ///thehill.com/blogs/congress-blog/economy-budget/246347-the-arguments-for-ex-im-noone-can-rebut.
} 
Table 7. The effect of US EXIM financing to small businesses on US exports

\begin{tabular}{lcll}
\multicolumn{1}{l}{ Dependent variable: $\log$ value of US exports $\ln X_{j k t}^{U S}$} & & \\
\hline & $(1)$ & $(2)$ & $(3)$ \\
\hline EXIM_small & -0.000 & & \\
& $(0.002)$ & & \\
EXIM_other & $0.005^{* *}$ & & \\
& $(0.002)$ & & \\
EXIM_small (past 2 yrs) & & 0.002 & \\
& & $0.003)$ & \\
EXIM_other (past 2 yrs) & & $(0.004)$ & \\
& & & -0.001 \\
EXIM_small (past 3 yrs) & & & $(0.004)$ \\
& & & 0.005 \\
EXIM_other (past 3 yrs) & & & $(0.005)$ \\
& & Yes & Yes \\
Other controls & Yes & Yes & Yes \\
Year fixed effects & Yes & Yes & Yes \\
Country-industry fixed effects & Yes & & \\
\hline N & 84,162 & 71,682 & 59,436 \\
Adj. R ${ }^{2}$ & 0.851 & 0.857 & 0.863 \\
\hline
\end{tabular}

Note. This table reports regression results on the effect of EXIM support extended to small businesses on US exports. EXIM_small is EXIM authorization to small businesses and EXIM_other is EXIM authorization to other businesses. Other variables are defined as in Table 5. Standard errors in parentheses are clustered at country-industry level. Superscripts $*, * *, * * *$ indicate significance at $10 \%, 5 \%$, and $1 \%$ levels respectively.

ample export financing through its state ECAs. In other words, without US EXIM financing, Jet Airways ${ }^{33}$ would not buy any Boeing aircrafts but would instead buy Bombardier aircrafts to benefit from export financing provided by the Canadian ECA, Export Development Canada.

In situations where export financing is indeed provided by the US EXIM Bank, there is a possibility that foreign companies may still not purchase American goods and instead buy goods from exporters whose countries are not regulated by the OECD Arrangement. This is because countries who are not participants to the OECD arrangement are not obligated to comply with the OECD limitations on the terms and conditions of export credit activity, and hence are able to provide for export credit at flexible terms and conditions. ${ }^{40}$ If we add another aircraft exporting country, China, into our example above, it would then imply that even if the US EXIM Bank, an ECA whose export credit activity is regulated by the Arrangement, provides export financing to Jet Airways to purchase Boeing aircraft, Jet Airways would probably opt to buy Chinese-made aircrafts as the export credit activities of China are not regulated by the Arrangement and hence are more able to provide lenient export credit terms and conditions to Jet Airways compared to what an Arrangement-regulated-USEXIM-Bank would have offered.

Anecdotal evidence also suggests that American exporters, without EXIM authorization, could have been at a disadvantage to foreign-ECA-financed-exporters, particularly to the ones that are not regulated by the Arrangement. For instance, John Murphy, the senior vice president of the US Chamber of Commerce, gives the example of a firm that sells US medical equipment in the Chinese

\footnotetext{
${ }^{33}$ Jet Airways is an Indian passenger carrier airline that travels on domestic and international routes.
} 
market who would not qualify to bid to do business in the Chinese health care system without the US EXIM Bank. ${ }^{34}$ In a similar vein, the D.C. District Court found that, without US EXIM support "airlines simply will purchase from Airbus instead of Boeing due to presence of foreign [export credit agency financing]".35

Even in situations where the US EXIM Bank actually provides export financing to support American exports, it is argued that the sheer volume of unregulated (by the Arrangement) ECA financing could have put American exporters at a financing disadvantage in the global marketplace. This is only evident in the fact that China, a non-Arrangement-compliant country, provided its exporters with at least US $\$ 670$ billion in ECA financing over a period of two years, while the US EXIM has equipped American exporters with only about US $\$ 590$ billion in financing over its entire 81-year history (US EXIM Bank, 2015). ${ }^{36}$

However, anecdotal evidence suggests that, whether to counteract foreign export credit agency competition, export financing provided by the US EXIM Bank may not have necessarily contributed to US exports. This is because a large portion of export financing is drawn from sources other than the US EXIM Bank. For instance, for the year 2013 and 2014, we estimate less than one-third of the estimated export value, i.e. US $\$ 12.2$ billion in 2013 and US $\$ 8.69$ billion in 2014, of the Bank's portfolio being directed to counteract competitive disadvantages created by foreign governments' ECA trade financing activities. ${ }^{37}$ Besides, in 2013 (2014), only 15\% (11\%) of total large commercial aircraft delivered by Boeing was "ECA supported" by the Bank while a whopping 48\% (54\%) was "ECA eligible, but not supported" (US EXIM Bank, 2013a, 2014). In fact, in a ruling on the Delta versus US EXIM Bank case, D.C. District Court asserts that EXIM financing is three times more expensive than Enhanced Equipment Trust Certificate (EETCs), which are asset-backed bonds used by domestic airlines to finance plane purchases. ${ }^{38}$ Even, between the participants to the OECD Arrangement, ECAs have increasingly turned to tools outside of the Arrangement (e.g. market windows, untied financing, and investment support) to finance projects abroad (US EXIM Bank, 2015).

Given these opposing anecdotal evidence, in this section we investigate this rising debate on whether US EXIM authorization enables US exporters to compete with foreign exporters that receive ample financing from their home-country ECAs. To do so, we use a number of measures to capture the effect of the competition the US faces from exports supported by other countries' ECAs. The first measures is constructed as

\footnotetext{
${ }^{34}$ http: //www.washingtonexaminer.com/the-pros-and-cons-of-reauthorizing-the-export-importbank/article/2551068.

${ }^{35}$ https : //www.uschamber.com/above-the-fold/costs-closing-ex-im-mount-house-vote-nears.

${ }^{36}$ According to the Office of the U.S. Trade Representative, the OECD Arrangement reportedly has saved US taxpayers about US $\$ 800$ million annually. The information can be accessed from the website of Office of United States Trade Representative at https://ustr.gov/trade-agreements/wto-multilateral-affairs/oecd.

${ }^{37}$ The requirement to categorize all loans and long-term guarantees in its annual report came through in the reauthorization of the US EXIM Bank in 2012. Therefore, we are able to calculate the estimated export value directed to meet foreign ECA competition for the years 2013 and 2014.

${ }^{38} \mathrm{http}$ ://thehill.com/blogs/congress-blog/economy-budget/246347-the-arguments-for-ex-im-noone-can-rebut.
} 


$$
G_{j, k, t}=\sum_{\substack{c=1, c \neq \cup S}}^{N} M_{j, k, c, t-1} I_{c, t-1}
$$

where $M_{j, k, c, t-1}$ is country $j$ 's imports of good $k$ from country $c$ in year $t-1$, and $I_{c, t}$ is a dummy that takes on the value of one when country $c$ has a government-backed export credit agencies. Table A2, Appendix A, provides a list of countries with the names of their respective government-backed export credit agencies.

The second measure takes further into account the similarity of the competing country's export structure to that of the US, based on the assumption that ceteris paribus when a country's bundle of exports to a market is more similar to the US exports in the same market, this country poses a stronger competition to the US and thus creates additional incentive for the US EXIM to support its exports to this market. Specifically, this measure takes the following form:

$$
G_{j, k, t}=\sum_{\substack{c=1, c \neq U S}}^{N} M_{j, k, c, t-1} I_{c, t-1} E S I_{c, t-1}^{U S}
$$

where $E S I_{c, t-1}^{U S}$ is the export similarity index measuring the overlap of country c's composition of exports with that of the US, defined a la Finger and Kreinin (1979) as

$$
E S I_{c, t-1}^{U S}=\sum_{k \in K} \min \left(s_{k, c, t-1}, s_{k, t-1}^{U S}\right)
$$

Here $E S I_{c, t-1}^{U S}$ varies between zero and one, with zero indicating completely different export structure and one representing identical export bundle to the US. Intuitively, (11) measures the competition US product $k$ faces in a foreign market $j$ in year $t$ from competing countries' ECAs, weighted by each country's similarity to the US in export bundle. For the ease of interpretation of the variation, both (10) and (11) are standardized so that they have a mean of zero and standard deviation of one.

The theoretical underpinning of the above two foreign competition measures is that a country's demand for foreign goods is intrinsic to the funds available to purchase this demand. Therefore, an exporting country that has a government-backed ECA has a greater potential to influence an importing country's demand for US products, especially when the exporting country's export structure is similar to that of the US. In other words, both ECA support and export structure similarity to the US would make an exporting country more of an competitor to US exports in the global market. ${ }^{39}$

\footnotetext{
${ }^{39}$ To put it simply, consider the following example. Supposing India has demands for aircrafts whose purchase depends largely on the internal and external funds at its disposal. Assume that the demand for external funds is greater than the available internal funds. While Indian buyers of aircraft can obtain the required funds from other sources of financing such as equity and debt markets, countries of aircraft manufacturers, through their ECAs, can also provide the required funds to the Indian buyer. Now suppose there are two countries that export aircrafts, the US which has a government backed export credit agency, and Brazil which does not. If the US provides export financing through its ECA, Indian buyers are more likely to make its aircrafts purchase from the US manufacturers than from the Brazilian counterparts irrespective of
} 
A look at the distributions of the two measures, (10) and (11), in Table 8 indicates that US exports to the European region face maximum competition from ECA-financed exports by other countries, and that the competition is stronger when the export bundles are more similar. On the contrary, it is the Caribbean region where the US exports face the least competition from ECA-financed exports by other countries. It should be noted that the relative ranking of the regions across the four measures is stable.

For the regression analysis, we introduce the interaction terms between the foreign ECA competition measures ( $G$ as defined in (10) or (11)) and the US EXIM authorization variable, and re-estimate eq. (5) on the country-industry-year sub-sample which includes all sectors other than aerospace products. From the results presented in columns 1-6 of Table 9, we see that the estimated coefficient of the interaction terms between US EXIM authorization and measures of foreign ECA competition sway between positive and negative values but remain invariably indifferent from zero in a statistical sense. These results indicate that the export-promoting effect of US EXIM authorization is not affected by foreign ECA competition, irrespective of which of the two foreign ECA competition measures we use.

Given the landscape of international commitments under various international institutional arrangements, competition for US exporters in the global marketplace may accentuate. In particular, while ECA-related export credit activities of the participants to the Arrangement have to follow the negotiated financing terms and conditions in the Arrangement, non-participants to the Arrangement are not obligated to do so. We therefore proceed to investigate whether the mediating effect of foreign ECA competition is influenced by competing countries' accession to the OECD Arrangement. ${ }^{40}$ In doing so, we further extend the above measures (13) and (14) by adding a multiplicative item $O E C D_{c, t-1}$ which indicates whether exporter $c$ is a signatory to the Arrangement in year $t-1$ :

$$
G_{j, k, t}=\sum_{\substack{c=1, c \neq \cup S}}^{N} M_{j, k, c, t-1} I_{c, t-1} O E C D_{c, t-1}
$$

the similarity of Brazil's exports and US exports to India, ceteris paribus. However, now consider a third country, Canada, who also exports aircraft and has a government-backed ECA. In addition, in terms of the composition of goods, there is more similarity between Canada's exports and US exports to India than that between Brazil's exports and US exports to India. In such a case, Indian buyers are more likely to make their aircraft purchases from the two countries with ECAs, i.e. US and Canada, ceteras paribus. Compared to Brazil, Canada is thus more of a competitor to the US in the Indian market.

${ }^{40}$ It should be noted that WTO members are also governed by WTO's "Agreement on Subsidies and Countervailing Measures" (SCM) which lists the conditions under which ECA financing provided by ECAs of WTO members shall be considered as export subsidies. Although the clause in WTO's SCM attempts to safeguard the interest of OECD Arrangement-participants, the ambiguity in the clause leaves room for countries to maneuver such that ECAs from countries, not Arrangement-participants but WTO members, tend to indulge in providing financing (to its exporters) at terms and conditions that are not viable by the Arrangement-participants. A case in point is the rising number of cases at the WTO for dispute settlements on the violation of the clause on export credits in the WTO's Agreement. One widely reported example is Canada's complaint at the WTO on Brazil violating the SCM Agreement; see the WTO webpage for more details on this disputed case: https://www.wto.org/english/tratop_e/dispu_e/cases_e/ds46_e.htm. While in principle both the Arrangement and SCM are binding regulatory frameworks for many competing countries of the US, SCM has a much more universal coverage. To be precise, in our data virtually all (98.4\%) of these competing countries' exports (in dollar values) are destined for WTO members, of which only half (51.6\%) land in OECD Arrangement countries. Therefore the OECD Arrangement effect we look at here captures the differential effect of the OECD Arrangement relative to WTO export credit regulations, as part of the impact of foreign ECA competition on US exports. 


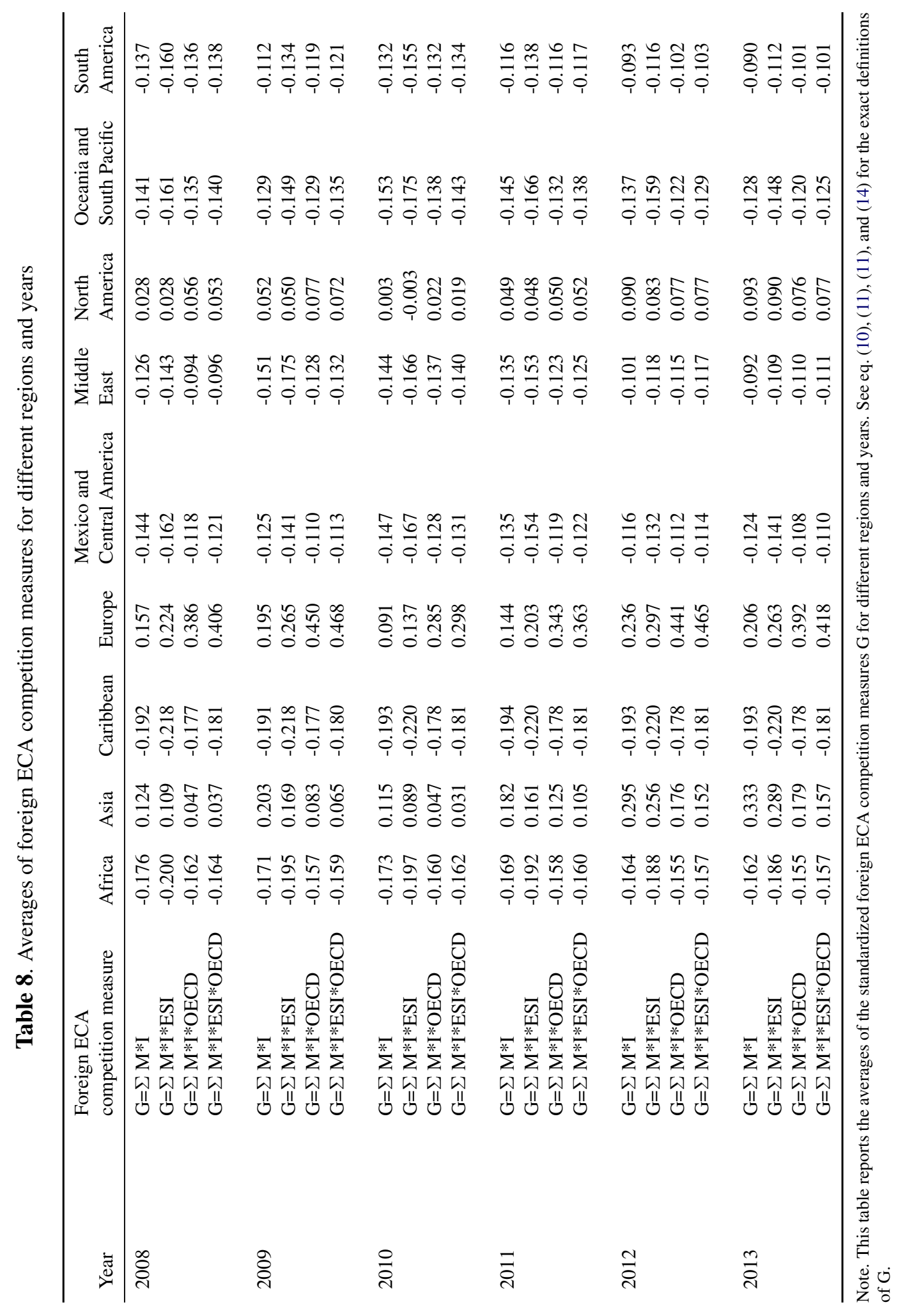




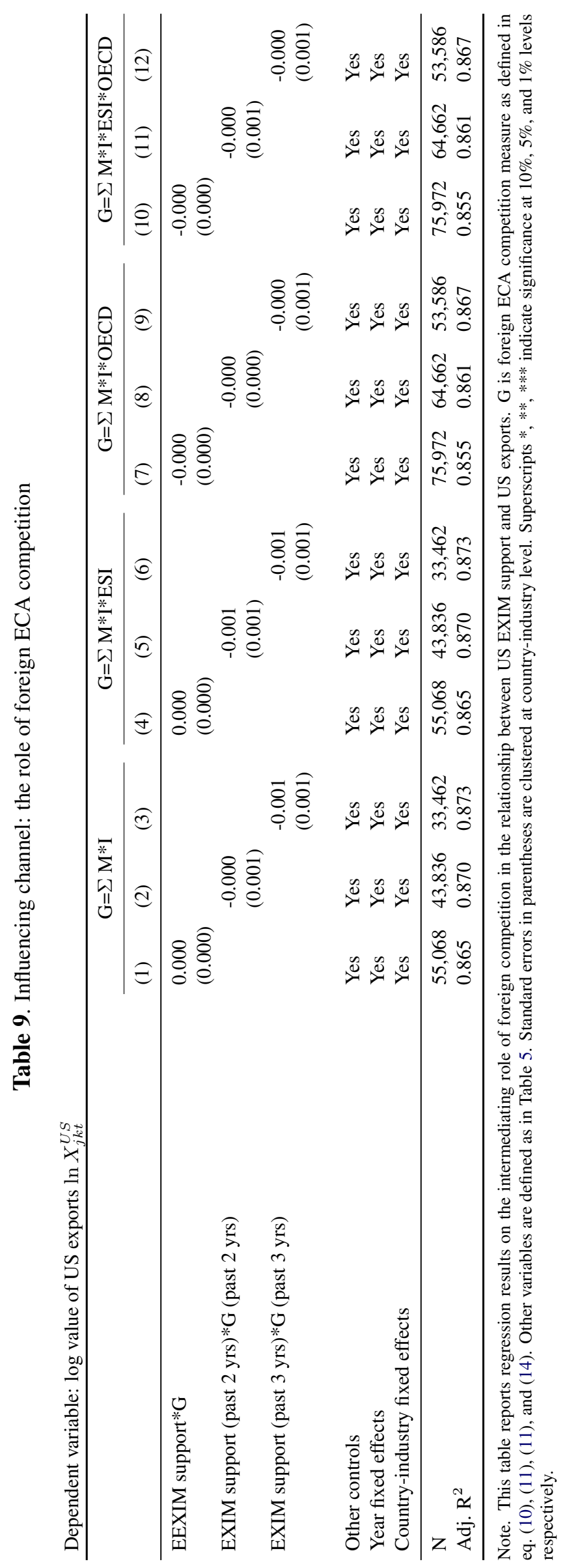




$$
G_{j, k, t}=\sum_{\substack{c=1, c \neq U S}}^{N} M_{j, k, c, t-1} I_{c, t-1} E S I_{c, t-1}^{U S} O E C D_{c, t-1}
$$

Again, both (13) and (14) are standardized so that their mean is zero and standard deviation is one. ${ }^{41}$

The results are reported in Table 9. Columns 7-12 show that competing countries' accession to the Arrangement has no additional impact on ECA competition effect. This result suggests that, ceteras paribus, US EXIM authorization has no effect on US exports to a market which is also sought after by competing countries who are governed by the OECD Arrangement. This finding is broadly consistent with the notion that the Arrangement ensures orderly and healthy competition between the participating members of the Arrangement.

We then examine whether the mediating effect of foreign ECA competition is influenced by the size of American companies who received funds from the US EXIM Bank. It is seen that EXIM authorization to small businesses has gone up in the recent years (see the previous section), and yet it is not clear whether support on small businesses creates more export opportunities as the Bank claims (US EXIM Bank, 2007, 2013a). We see from columns 1-6 of Table 10 that in general EXIM support, whether it is on small or larger companies, does not play a significant role in determining the conditioning effect of foreign ECA competition. Columns 7-12 show that the differential effect of the OECD Arrangement is mostly insignificant, except on one occasion (column 10) where the effect is marginally significant at the $10 \%$ level and a one standard deviation increase in this competition measure reduces the export effect of EXIM support by $0.1 \%$ when US exporters are competing against ECA-supported exports from OECD countries with a similar export structure to the US.

To summarize, we find that, regardless of the degree of ECA-financed export competition which US firms face in a foreign market, US EXIM Bank's support does not promote US exports in a detectable way. Besides, the size of American companies that receive the EXIM support or competing countries accession to the Arrangement also does not determine the conditioning effect of foreign ECA competition.

\subsection{Industry upstreamness and cross-industry effects of EXIM authorization}

Now we assess the effects of EXIM authorization in the context of US domestic value chains. We first look at how EXIM authorization affects firms located in different sections of the value chain. In theory it is not clear whether upstream sectors benefit more or less from EXIM finance than downstream sectors. On the one hand, since upstream sectors rely heavily on the domestic market, EXIM authorization on firms in these sectors may not benefit their exports as much as in downstream sectors. On the other hand, if the US firms in US upstream sectors are also major upstream suppliers in the global market (e.g. firms in the oil industry), EXIM authorization may boost their exports. To have an empirical answer to the net effect, we interact EXIM authorization with a continuous measure of the sector's upstreamness in the US economy adopted from Antràs et al. (2012). The

\footnotetext{
${ }^{41}$ The four measures of foreign ECA competition are highly correlated with each other, with the pairwise correlation coefficient constantly above 0.77 and significant at the $1 \%$ level. See Table A3, Appendix A for the correlation matrix.
} 


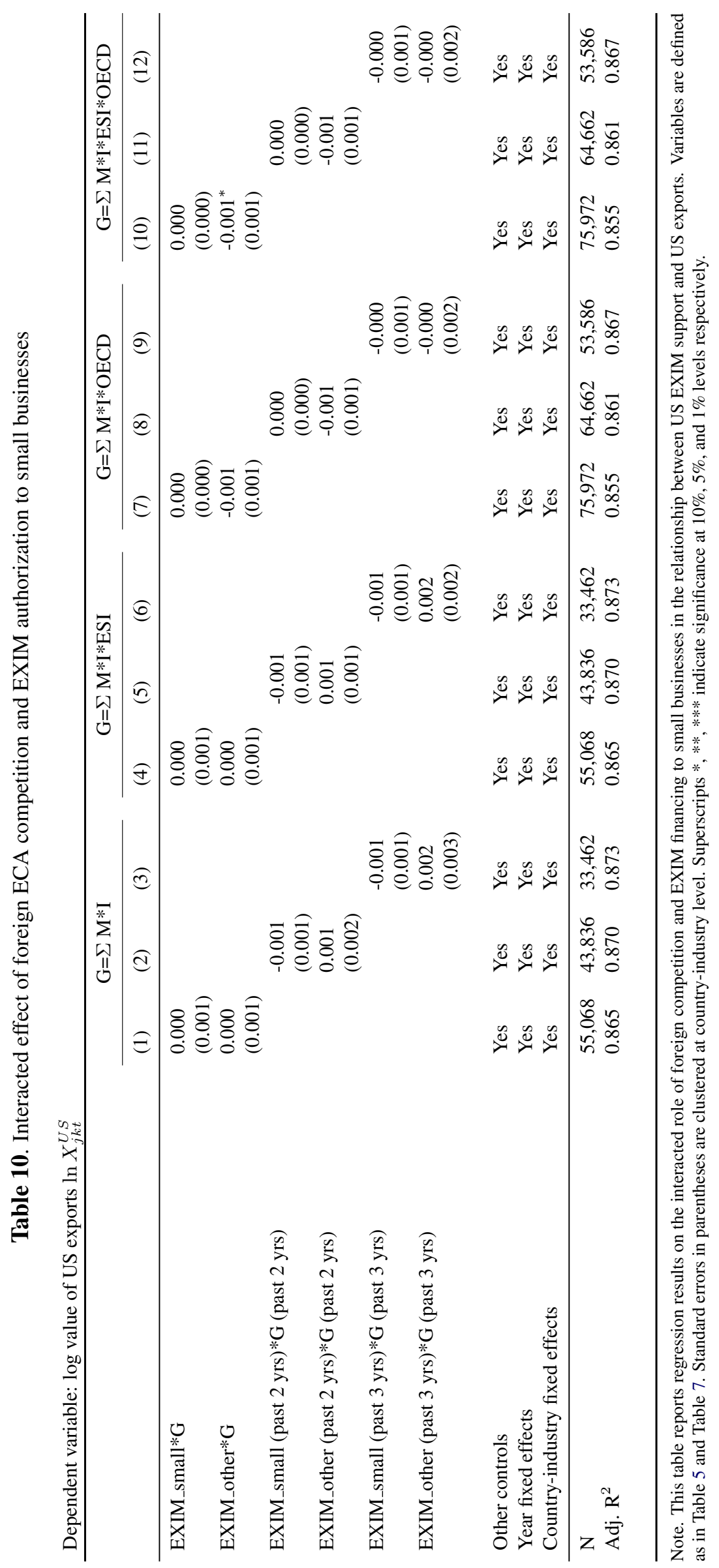


results are presented in Table 11. The estimates from models of different time lags show that the export-promoting effects of EXIM support are lower in sectors that are located more towards the upper end of the value chain, but none of these interactions show statistically significance, suggesting that the differences are indistinguishable.

Table 11. Industry heterogeneity - the role of industries' positions in the value chain

\begin{tabular}{|c|c|c|c|}
\hline & (1) & (2) & (3) \\
\hline EXIM support & $\begin{array}{l}0.008 \\
(0.005)\end{array}$ & & \\
\hline EXIM support*Upstreamness & $\begin{array}{l}-0.002 \\
(0.003)\end{array}$ & & \\
\hline EXIM support (past 2 yrs) & & $\begin{array}{l}0.008 \\
(0.008)\end{array}$ & \\
\hline EXIM support (past 2 yrs)*Upstreamness & & $\begin{array}{l}-0.001 \\
(0.004)\end{array}$ & \\
\hline EXIM support (past 3 yrs) & & & $\begin{array}{l}0.009 \\
(0.010)\end{array}$ \\
\hline EXIM support (past 3 yrs)*Upstreamness & & & $\begin{array}{l}-0.003 \\
(0.005)\end{array}$ \\
\hline Other controls & Yes & Yes & Yes \\
\hline Year fixed effects & Yes & Yes & Yes \\
\hline Country-industry fixed effects & Yes & Yes & Yes \\
\hline $\mathrm{N}$ & 84,162 & 71,682 & 59,436 \\
\hline Adj. $\mathrm{R}^{2}$ & 0.851 & 0.857 & 0.863 \\
\hline
\end{tabular}

Note. This table reports regression results on how the effect of US EXIM support on US exports differs across industries of different positions in the US value chain. Variables are defined as in Table 5. Standard errors in parentheses are clustered at country-industry level. Superscripts *, **, *** indicate significance at 10\%, 5\%, and $1 \%$ levels respectively.

Next we check the cross-industry spillover effect of EXIM authorization. Specifically, we are interested in how EXIM authorization to firms in a given industry affects the exports of other industries that are suppliers or buyers to this given industry. An underlying hypothesis is that EXIM support on exports of intermediate inputs in upstream industries may fuel the growth of downstream industries in other countries and thus creates additional competition to US downstream exporters. This possibility suggests the necessity of checking the externality of EXIM authorization across industries.

To measure the spillover effect of EXIM authorization from other linked industries in the value chain, we weight EXIM authorization in other industries by the cross-industry linkages constructed from input-output coefficients. ${ }^{42}$ We use two measures to capture the spillover effect on a given industry in the value chain, one through its links with upstream industries (supplying industries) and the other through its links with downstream industries (demanding industries). The first takes the form of

$$
\text { Upstream }_{k t} \equiv \sum_{q=1}^{M} \alpha_{k q} E_{X I M},
$$

\footnotetext{
${ }^{42}$ Some other studies such as Javorcik (2004) and Amiti and Smarzynska Javorcik (2008) construct and apply crossindustry linkages in a similar way albeit in different contexts.
} 
where $\alpha_{k q}$ is the proportion of industry $k$ 's total input that is supplied from industry $q$, and $E X I M_{q t}$ is the total EXIM support in industry $q$ in year $t$. The above measure captures the amount of linked EXIM support in the upstream industries (supplying industries) of industry $k$ in year $t$. The second takes the form of

$$
\text { Downstream }_{k t} \equiv \sum_{q=1}^{M} \beta_{k q} E X I M_{q t} \text {, }
$$

where $\beta_{k q}$ is the proportion of industry $k$ 's total output that is supplied to industry $q$, and $E X I M_{q t}$ is the total EXIM authorization in industry $q$ in year $t$. This measure captures the amount of linked EXIM authorization in the downstream industries (demanding industries) of industry $k$ in year $t$. The two parameters for the above cross-industry linkages, $\alpha_{k q}$ and $\beta_{k q}$, are from the US Input-Output Table 2007.

Note that since the above cross-industry measures of EXIM authorization are only available at the industry-year level, we now aggregate our data to the same level for regressions. Without previously used control variables at a more disaggregated level, our regressions here only serve descriptive purposes. The results, shown in Table 12, suggest that EXIM authorization has no statistically significant impact both within and across industries.

Table 12. Spillover effect of EXIM authorization along the value chain

\begin{tabular}{|c|c|c|c|}
\hline & (1) & (2) & (3) \\
\hline Within-industry EXIM support & $\begin{array}{l}0.001 \\
(0.001)\end{array}$ & & \\
\hline Upstream EXIM support & $\begin{array}{l}-0.006 \\
(0.010)\end{array}$ & & \\
\hline Downsream EXIM support & $\begin{array}{l}-0.001 \\
(0.011)\end{array}$ & & \\
\hline Within-industry EXIM support (past 2 yrs) & & $\begin{array}{l}-0.001 \\
(0.002)\end{array}$ & \\
\hline Upstream EXIM support (past 2 yrs) & & $\begin{array}{l}-0.017 \\
(0.015)\end{array}$ & \\
\hline Downstream EXIM support (past 2 yrs) & & $\begin{array}{l}0.002 \\
(0.015)\end{array}$ & \\
\hline Within-industry EXIM support (past 3 yrs) & & & $\begin{array}{l}-0.001 \\
(0.003)\end{array}$ \\
\hline Upstream EXIM support (past 3 yrs) & & & $\begin{array}{l}-0.012 \\
(0.019)\end{array}$ \\
\hline Downstream EXIM support (past 3 yrs) & & & $\begin{array}{l}0.004 \\
(0.024)\end{array}$ \\
\hline Year fixed effects & Yes & Yes & Yes \\
\hline $\mathrm{N}$ & 651 & 558 & 465 \\
\hline Adj. $\mathrm{R}^{2}$ & 0.990 & 0.994 & 0.995 \\
\hline
\end{tabular}

Note. This table reports regression results on the effect US EXIM support spill over to other industries in the US value chain. The dependent variable is the $\log$ value of US exports $\ln X_{j k t}^{U S}$. The explanatory variables are defined in the text of Section 6.4. Standard errors in parentheses are clustered at country-industry level. Superscripts *,**, *** indicate significance at $10 \%, 5 \%$, and $1 \%$ levels respectively. 


\section{Conclusions}

In this paper, we provide evidence on the export-promoting effects of US EXIM Bank authorization. We find that EXIM authorization does not affect US exports across all industries. In fact, it is sectors other than that of aerospace parts and products (NAICS 3364) where EXIM authorization has a positive and significant impact on US exports. Moreover, we find that it is those American businesses that are not classified as small whose exports are more likely to benefit from EXIM authorization. No export benefit from EXIM authorization to small American businesses is detectable. We also find no evidence on whether financing provided by competing countries' ECAs accentuates competition for US exporters in the global marketplace. These results do not change qualitatively when we control for competing exporters' accession to the OECD Arrangement. When taking into account inter-industrial links in the value chain, our results show that the above-found ineffectiveness of EXIM authorization is insensitive to an industry's position in the value chain, and also no evidence affirms the existence of spillover effect of EXIM support across sectors.

Our paper contributes to the growing literature that studies the impact of ECA financing on country exports. Yet, to the best of our knowledge, ours is the first study that provides rigorous empirical evidence in relation to the claims that the US EXIM Bank facilitates US exports through its trade financing programs, and in doing so helps US exporters to counter government-backed financing offered by foreign countries through their ECAs.

The findings in this study also provide important policy lessons for countries, especially lower middle-income countries (e.g. Ghana) that are now in the inception stages of establishing their own ECAs, and other countries (e.g. India and Thailand) that are placing ever more importance to ECA financing in encouraging domestic exports. A possible avenue of future research which is in our agenda is to have a cross-country study of the effect of ECA trade financing activities and investigate the policy making process behind the establishment and running of ECAs across countries of different political regimes.

\section{References}

Amiti, M. AND B. SMARZYNSKa JAVORCIK (2008): "Trade Costs and Location of Foreign Firms in China," Journal of Development Economics, 85(1-2), 129-149.

Amiti, M. AND D. E. Weinstein (2011): "Exports and Financial Shocks," Quarterly Journal of Economics, 126(4), 1841-1877.

Anderson, J. E. AND E. van Wincoop (2003): "Gravity with Gravitas: A Solution to the Border Puzzle," American Economic Review, 93(1), 170-192.

Antràs, P., D. Chor, T. FAlly, And R. Hillberry (2012): "Measuring the Upstreamness of Production and Trade Flows," American Economic Review: Papers and Proceedings, 102(3), 412-416.

Auboin, M. (2009a): "Boosting the Availability of Trade Finance in the Current Crisis: Background 
Analysis for a Substantial G20 Package,” CEPR Policy Insight No. 35.

(2009b): "Restoring Trade Finance in Periods of Financial Crisis: Stock- Taking of Recent Initiatives," WTO Staff Working Paper ERSD-2009-16.

Auboin, M. And M. Engemann (2013): "Trade Finance in Periods of Crisis: What Have We Learned in Recent Years," WTO Staff Working Paper ERSD-2013-01.

(2014): "Testing the Trade Credit and Trade Link: Evidence from Data on Export Credit Insurance," Review of World Economics, 150(4), 715-743.

Auboin, M. And M. Meier-Ewert (2003): "Improving the Availability of Trade Finance During Financial Crises,” WTO Discussion Paper Series.

BAdinger, H. AND T. URL (2013): "Export Credit Guarantees and Export Performance: Evidence from Austrian Firm-level Data," The World Economy, 36(9), 1115-1130.

Baier, S. L. And J. H. Bergstrand (2009): "Bonus vetus OLS: A Simple Method for Approximating International Trade-Cost Effects using the Gravity Equation," Journal of International Economics, 77(1), 77-85.

Berger, D., W. Easterly, N. Nunn, And S. Satyanath (2013): “Commercial Imperialism? Political Influence and Trade during the Cold War," American Economic Review, 103(2), 863-96.

Bernard, A. B. AND J. B. Jensen (1995): "Exporters, Jobs, and Wages in U.S. Manufacturing: 1976-1987," Brookings Papers on Economic Activity: Microeconomics, 1995, 67-112.

Chor, D. AND K. Manova (2012): "Off the Cliff and Back? Credit Conditions and International Trade during the Global Financial Crisis," Journal of International Economics, 87(1), 117-133.

DE RugY, V. (2014): “The Export-Import Bank Assists a Tiny Portion of All US Small Business Jobs and Firms," The Mercatus Center, George Mason University.

Egger, P. AND T. URL (2006): "Public Export Credit Guarantees and Foreign Trade Structure: Evidence from Austria," The World Economy, 29(4), 399-418.

Felbermayr, G. J. And E. YAlcin (2013): "Export Credit Guarantees and Export Performance: An Empirical Analysis for Germany," The World Economy, 36(8), 967-999.

Hecker, J. (1997): "Key Factors in Considering EXIM Bank Reauthorization," GAO/T-NSIAD97-215.

ICC (2016): "Rethinking Trade and Finance," Global Survey on Trade Finance.

InTERnATIONAL FinANCIAL Consulting LtD. (2012): "Study on Short-Term Trade Finance and Credit Insurance in the European Union," For European Union.

ISMED (2011): “Mediterranean Guarantees,” Newsletter Issue 2.

JAMES, S. (2011): “Time to X Out the Ex-Im Bank," Cato Institute Trade Policy Analysis No. 47.

JAVORCIK, B. S. (2004): "Does Foreign Direct Investment Increase the Productivity of Domestic Firms? In Search of Spillovers Through Backward Linkages," American Economic Review, 94(3), 605-627.

Korinek, J., J. L. CocGuic, And P. Sourdin (2010): “The Availability and Cost of Short-Term 
Trade Finance and its Impact on Trade,” OECD Trade Policy Papers No. 98.

Manova, K. (2013): “Credit Constraints, Heterogeneous Firms, and International Trade," Review of Economic Studies, 80(2), 711-744.

Manova, K., S.-J. WeI, AND Z. Zhang (2015): "Firm Exports and Multinational Activity Under Credit Constraints," Review of Economics and Statistics, 97(3), 574-588.

Moser, C., T. Nestmann, And M. Wedow (2008): "Political Risk and Export Promotion: Evidence from Germany," The World Economy, 31(6), 781-803.

Paravisini, D., V. Rappoport, P. Schnabl, And D. Wolfenzon (2014): "Dissecting the Effects of Credit Supply on Trade: Evidence from Matched Credit-Export Data," Review of Economic Studies, 82(1), 333-359.

Prete, S. D. AND S. Federico (2014): "Trade and Finance: Is There More Than Just 'Trade Finance'? Evidence From Matched Bank-Firm Data,' Temi di Discussione No. 948, Banca D’Italia.

Silva, J. M. C. S. And S. Tenreyro (2006): "The Log of Gravity," Review of Economics and Statistics, 88(4), 641-658.

US EXIM BANK (2007): Annual Report: Export-Import Bank of the United States.

- (2013a): Annual Report: Export-Import Bank of the United States.

(2013b): EX-IM Bank Strategic Plan 2010-2015.

(2014): Report to the U.S. Congress on Global Export Credit Competition.

- (2015): Report to the U.S. Congress on Global Export Credit Competition.

USITC (2010): "Small and Medium-Sized Enterprises: Overview of Participation in US exports," USITC Publication 4125.

VAN DER VeER, K. J. M. (2015): “The Private Export Credit Insurance Effect on Trade,” Journal of Risk and Insurance, 82(3), 601-624.

Weaver, V. (2002): “2001 FCIB Conference: Credit Management in Troubled Times," Business Credit, 104, 44. 


\section{A Appendix}

Table A1. Baseline results: alternative sample and regression method

Dependent variable (columns 1-3): value of US exports $X_{j k t}^{U S}$

Dependent variable (columns 4-6): $\log$ value of US exports $\ln X_{j k t}^{U S}$

\begin{tabular}{|c|c|c|c|c|c|c|}
\hline & \multicolumn{3}{|c|}{$\begin{array}{l}\text { Poisson regressions, } \\
\text { Sample: whole sample }\end{array}$} & \multicolumn{3}{|c|}{$\begin{array}{c}\text { OLS, } \\
\text { Sample: EXIM support }>0\end{array}$} \\
\hline & (1) & (2) & (3) & (4) & $(5)$ & (6) \\
\hline EXIM support & $\begin{array}{l}0.002 \\
(0.003)\end{array}$ & & & $\begin{array}{l}0.014 \\
(0.016)\end{array}$ & & \\
\hline EXIM support (past 2 yrs) & \multicolumn{3}{|c|}{$\begin{array}{l}0.003 \\
(0.004)\end{array}$} & \multicolumn{3}{|c|}{$\begin{array}{l}0.000 \\
(0.006)\end{array}$} \\
\hline EXIM support (past 3 yrs) & & & $\begin{array}{l}0.008 \\
(0.008)\end{array}$ & & & $\begin{array}{l}0.000 \\
(0.006)\end{array}$ \\
\hline Other controls & Yes & Yes & Yes & Yes & Yes & Yes \\
\hline Year fixed effects & Yes & Yes & Yes & Yes & Yes & Yes \\
\hline Country-industry fixed effects & Yes & Yes & Yes & Yes & Yes & Yes \\
\hline $\mathrm{N}$ & 80,590 & 68,354 & 56,197 & 1,446 & 1,272 & 1,096 \\
\hline Adj. $R^{2}$ & & & & 0.966 & 0.978 & 0.989 \\
\hline
\end{tabular}

Note. This table reports regression results using alternative regression method and data sample. Variables are defined as in Table 5. Standard errors in parentheses are clustered at country-industry level. Superscripts $*, * *, * * *$ indicate significance at $10 \%, 5 \%$, and $1 \%$ levels respectively.

Table A2. List of official state export credit agencies across the world

\begin{tabular}{ll}
\hline Country & State Export Credit Agency \\
\hline Algeria & Compagnie Algerienne D'Assurance et du Garantie des Exportation \\
Argentina & Banco de Inversion y Comercio Exterior \\
Armenia & Export Insurance Agency of America \\
Australia & The Export Finance Insurance Corporation \\
Austria & Oesterreichische Kontrollbank Aktiengesellschaft (OeKB) \\
Bangladesh & Sadharan Bima Corporation Export Credit Guarantee Department \\
Barbados & Central Bank of Barbados \\
Belarus & Eximgarant of Belarus \\
Belgium & Credendo Group \\
Belgium & Delcredere - Ducroire \\
Bermuda & Hiscox Political Risk \\
Bermuda & Sovereign Risk Insurance Ltd (Sovereign) \\
Bosnia and Herzegovina & Investment Guarantee Agency \\
Botswana & Export Credit and Guarantee Company (BECI) \\
Brazil & Agencia Brasileria Gestora Fundos Garantidores e Garantias S.A. \\
Brazil & Banco National de Desenvolvimento Economico e Social - BNDES \\
Brazil & Brazilian Export Credit Insurance Agency \\
Bulgaria & Bulgarian Export Insurance Agency \\
Canada & Export Development Canada \\
China & China Export and Credit Insurance Corporation (SINO SURE) \\
China & Export Import Bank of China \\
& \\
\hline
\end{tabular}


Table A2. - List of export credit agencies (ECAs) across the world (continued)

\begin{tabular}{|c|c|}
\hline Country & State Export Credit Agency \\
\hline Colombia & Fondo Nacional de Garantias S.A. (FNG) \\
\hline Colombia & Banco de Comercio Exterior de Colombia (Bancoldex) \\
\hline Croatia & Croatian Bank for Reconstruction and Development (HBOR) \\
\hline Cyprus & Export Credit Insurance Service (ECIS) \\
\hline Czech Republic & Export Guarantee Insurance Corporation (EGAP) \\
\hline Czech Republic & Czech Export Bank, a.s. \\
\hline Denmark & Eksport Kredit Fonde \\
\hline Egypt & Export Credit Guarantee Company of Egypt (ECGE) \\
\hline Estonia & KredEx \\
\hline Estonia & KredEx Credit Insurance Ltd \\
\hline Finland & Finnvera Plc \\
\hline Finland & Finnish Export Credit Ltd (FEC) \\
\hline France & Compagnie Francaise d' Assurance pour le Commerce Exterieur (COFACE)* \\
\hline Germany & Euler Hermes Deutschland (AG) \\
\hline Germany & PricewaterCoopers AG (PwC) \\
\hline Germany & Euler Hermes \\
\hline Ghana & Ghana Export Import Bank \\
\hline Greece & Export Credit Insurance Organization (ECIO) \\
\hline Hong Kong & Hong Kong Export Credit Insurance Corporation (HKEC) \\
\hline Hungary & Hungarian Export-Import Bank Plc \\
\hline Hungary & Hungarian Export Credit Insurance Plc \\
\hline India & Export Credit Guarantee Corporation of India Ltd \\
\hline India & Export Import Bank of India \\
\hline Indonesia & Indonesian Eximbank \\
\hline Indonesia & PT. Asuransi Ekspor Indonesia (Persero) (Asuransi ASEI) \\
\hline Iran & Export Guarantee Fund of Iran \\
\hline Ireland & The Insurance Corporation of Ireland (ICI) \\
\hline Israel & Israel Export Insurance Corp Ltd (ASHRA) \\
\hline Italy & Servizi Assicurativi del Credito all' Esportazione (SACE) \\
\hline Italy & Societa Italiana per le Imprese all'Estero (Simest SpA) \\
\hline Jamaica & National Export-Import Bank of Jamaica Limited \\
\hline Japan & Nippon Export and Investment Insurance (NEXI) \\
\hline Japan & Japan Bank for International Cooperation \\
\hline Jordan & Jordan Loan Guarantee Corporation (JLGC) \\
\hline Kazakhstan & KazExportGarant Export Credit Insurance Corporation (KAZEXPORTGARANT) \\
\hline South Korea & Korea Trade Insurance Corporation (KSURE) \\
\hline South Korea & The Export-Import Bank of Korea \\
\hline Latvia & Latvian Guarantee Agency (LGA) \\
\hline Lebanon & Lebanese Credit Insurer (LCI) \\
\hline Lithuania & INVEGA \\
\hline Luxembourg & Luxembourg Export Credit Agency (ODL) \\
\hline Macedonia & Macedonia Bank for Development Promotion \\
\hline Malaysia & Export-Import Bank of Malaysia Berhad \\
\hline Malta & Malta Export Credit Guarantee Company \\
\hline Mexico & Banco Nacional de Comercio Exterior S.N.C. (BANCOMEXT) \\
\hline Netherlands & Altradius NV \\
\hline \multirow[t]{2}{*}{ New Zealand } & Export Credit Office (ECO) \\
\hline & (Continued on next page) \\
\hline
\end{tabular}


Table A2. - List of export credit agencies (ECAs) across the world (continued)

\begin{tabular}{|c|c|}
\hline Country & State Export Credit Agency \\
\hline Nigeria & Nigerian Export-Import Bank (NEXIM) \\
\hline Norway & Garanti-Instituttet for Eksportkreditt (GIEK) \\
\hline Norway & Export Credit Norway (Eksportkreditt Norge AS) \\
\hline Oman & Export Credit Guarantee Agency of Oman SAOC (ECGA Oman) \\
\hline Philippines & Philippine Export-Import Credit Agency \\
\hline Poland & Export Credit Insurance Corporation Joint Stock Company (KUKE) \\
\hline Portugal & Companhia de Seguro de Creditos, S.A. (COSEC) \\
\hline Qatar & Qatar Development Bank \\
\hline Romania & Exim Bank of Romania \\
\hline Russia & Export Insurance Agency of Russia \\
\hline Saudi Arabia & Saudi Export Program \\
\hline Senegal & Societe Nationale d'Assurances du Credit et du Cautionment \\
\hline Serbia & AOFI - Export Credit and Insurance Agency of the Republic of Serbia \\
\hline Singapore & ECICS Ltd \\
\hline Slovak Republic & Export-Import Bank of the Slovak Republic \\
\hline Slovenia & SID Inc, Ljubljana (SID) \\
\hline South Africa & Export Credit Insurance Corporation os South Africa \\
\hline Spain & Compania Espanola de Seguros de Credito a la Exportacion (CESCE) \\
\hline Spain & Secretaria de Estado de Comercio (Ministerio de Economia) \\
\hline Spain & Instituto de Credito Oficial (ICO) \\
\hline Sri Lanka & Sri Lanka Export Credit Insurance Corporation (SLECIC) \\
\hline Sudan & National Agency for Insurance and Finance of Export of Sudan \\
\hline Sweden & Exportkreditnamnden \\
\hline Sweden & Svensk Exportkredit \\
\hline Switzerland & Swiss Export Risk Insurance (SERV) \\
\hline Taiwan & Taipei Export-Import Bank of China (TEBC) \\
\hline Thailand & Export Import Bank of Thailand \\
\hline Trinidad and Tobago & Export Import Bank of Trinidad and Tobago \\
\hline Tunisia & Compagnie Tunisienne Pour L'Assurance Du Commerce Exterieur (CONTUNACE) \\
\hline Turkey & Export Credit Bank of Turkey \\
\hline Ukraine & The State Export Import Bank of Ukraine \\
\hline UAE & Export Credit Insurance Co. of the Emirates \\
\hline UK & Export Credit Guarantee Department (UK Export Finance) \\
\hline USA & Export Import Bank of the United States of America \\
\hline Uruguay & Banco de Seguros del Estado \\
\hline Uzbekistan & UZBEKINVEST National Export-Import Insurance Company \\
\hline Vietnam & Vietnam Development Bank \\
\hline Zimbabwe & Credit Insurance Zimbabwe Ltd (CREDSURE) \\
\hline
\end{tabular}

* On December 31, 2016, France's COFACE transferred its export credit activities to Bpifrance Assurance Export S.A.S. through the Amending Finance Law No. 2015-1786 dated December 29, 2015. See: https://www.whitecase.com/publications/alert/transfer-french-export-credit-activities-coface-bpifranceassurance-export-sas. 
Table A3. Correlation coefficients of foreign ECA competition measures

\begin{tabular}{|c|c|c|c|c|}
\hline & $\mathrm{G}=\Sigma \mathrm{M} * \mathrm{I}$ & $\mathrm{G}=\Sigma \mathrm{M} * \mathrm{I} * \mathrm{ESI}$ & $\mathrm{G}=\Sigma \mathrm{M} * \mathrm{I} * \mathrm{OECD}$ & $\mathrm{G}=\Sigma \mathrm{M}^{*} \mathrm{I}^{*} \mathrm{ESI} \mathrm{I}^{*} \mathrm{OECD}$ \\
\hline $\mathrm{G}=\Sigma \mathrm{M} * \mathrm{I}$ & 1.000 & & & \\
\hline $\mathrm{G}=\Sigma \mathrm{M} * \mathrm{I} * \mathrm{ESI}$ & $\begin{array}{l}0.940 \\
(0.000)\end{array}$ & 1.000 & & \\
\hline $\mathrm{G}=\Sigma \mathrm{M} * \mathrm{I} * \mathrm{OECD}$ & $\begin{array}{l}0.809 \\
(0.000)\end{array}$ & $\begin{array}{l}0.935 \\
(0.000)\end{array}$ & 1.000 & \\
\hline $\mathrm{G}=\Sigma \mathrm{M} * \mathrm{I} * \mathrm{ESI} * \mathrm{OECD}$ & $\begin{array}{l}0.774 \\
(0.000)\end{array}$ & $\begin{array}{l}0.924 \\
(0.000)\end{array}$ & $\begin{array}{l}0.990 \\
(0.000)\end{array}$ & 1.000 \\
\hline
\end{tabular}

Note. This table reports the correlation coefficients of the four measures of foreign ECA competition used in this research. Standard errors are in parentheses. 